\title{
Work-related stress and well-being in association with epigenetic age acceleration: A Northern Finland Birth Cohort 1966 Study
}

\author{
Anna Freni-Sterrantino ${ }^{1}$, Giovanni Fiorito ${ }^{1,2}$, Angelo D'Errico ${ }^{3}$, Oliver Robinson ${ }^{1}$, \\ Marianna Virtanen ${ }^{4,5}$, Leena Ala-Mursula ${ }^{6}$, Marjo-Riitta Järvelin ${ }^{1,6}$, Justiina Ronkainen ${ }^{6}$, \\ Paolo Vineis ${ }^{1,7,8}$
}
${ }^{1} \mathrm{MRC}$ Centre for Environment and Health, Department of Epidemiology and Biostatistics, Imperial College London, St Mary's Campus, London W2 1PG, United Kingdom
${ }^{2}$ Laboratory of Biostatistics, Department of Biomedical Sciences, University of Sassari, Sassari 07100, Italy
${ }^{3}$ Department of Epidemiology, Local Health Unit TO 3, Turin 10095, Italy
${ }^{4}$ School of Educational Sciences and Psychology, University of Eastern Finland, Joensuu FI-80101, Finland
${ }^{5}$ Division of Insurance Medicine, Karolinska Institutet, Stockholm 17177, Sweden
${ }^{6}$ Center for Life Course Health Research, Faculty of Medicine, University of Oulu, Oulu 90014, Finland
${ }^{7}$ Grantham Institute for Climate Change and School of Public Health, Imperial College London, London SW7 2AZ,
United Kingdom
${ }^{8}$ IIGM - Italian Institute for Genomic Medicine (IIGM), IRCCS Candiolo, Torino 10060, Italy
Correspondence to: Anna Freni-Sterrantino; email: a.freni-sterrantino@imperial.ac.uk
Keywords: epigenetic age, job strain, effort-reward imbalance, work-related well-being, DNA methylation
Received: September 4, $2021 \quad$ Accepted: January 25, $2022 \quad$ Published: February 2, 2022

Copyright: (C) 2022 Freni-Sterrantino et al. This is an open access article distributed under the terms of the Creative Commons Attribution License (CC BY 3.0), which permits unrestricted use, distribution, and reproduction in any medium, provided the original author and source are credited.

\section{ABSTRACT}

Recent evidence indicates consistent association of low socioeconomic status with epigenetic age acceleration, measured from DNA methylation. As work characteristics and job stressors are crucial components of socioeconomic status, we investigated their association with various measures of epigenetic age acceleration.

The study population included employed and unemployed men and women $(n=604)$ from the Northern Finland Birth Cohort 1966. We investigated the association of job strain, effort-reward imbalance and work characteristics with five biomarkers of epigenetic aging (Hannum, Horvath, PhenoAge, GrimAge, and DunedinPoAm).

Our results indicate few significant associations between work stress indicators and epigenetic age acceleration, limited to a range of \pm 2 years, and smoking recording the highest effect on GrimAge age acceleration biomarker between current and no smokers (median difference 4.73 years (IQR 1.18, 8.41). PhenoAgeAA was associated with job strain active work $(\beta=-1.30195 \% \mathrm{Cl}-2.391,-0.212)$, slowing aging of less than 1.5 years, and working as white-collar slowed aging six months (GrimAgeAA $\beta=-0.683,95 \% \mathrm{Cl}-1.264$, 0.102) when compared to blue collars. Association was found for working for more than 40 hours per week that increased the aging over 1.5 years, (HorvathAA $\beta=2.05895 \% \mathrm{Cl} 0.517,3.599$, HannumAA $\beta=1.567,95 \% \mathrm{Cl}$ $0.415,2.719)$.

The pattern of associations was different between women and men and some of the estimated effects are inconsistent with current literature. Our results provide the first evidence of association of work conditions with epigenetic aging biomarkers. However, further epidemiological research is needed to fully understand how work-related stress affects epigenetic age acceleration in men and women in different societies. 


\section{INTRODUCTION}

DNA methylation-based biomarkers of biological age [1] - epigenetic clocks - have become very popular and have been found to be associated with several risk factors for non-communicable diseases and longevity [2]. Epigenetic clocks are a composite score of DNA methylation levels at different $\mathrm{CpG}$ sites in the genome. The differences between epigenetic clocks and chronological age have been defined as epigenetic age acceleration (EAA). Positive values of EAA indicate that an individual is experiencing accelerated aging. EAA has been found to predict all-cause mortality, frailty, psychosocial stress [3, 4], cardiovascular disease [5], diabetes, cancer $[1,6]$, and higher values are associated with a decline in cognitive ability, depression and anxiety $[7,8]$.

Previous studies [9-13] has suggested that low socioeconomic status (SES) is associated with EAA, using different proxies such as education, parental occupation, income, and combined measures like the relative index of inequality. It emerges that the detrimental effect of low SES positions starting early in life are detectable through epigenetic clocks [14]. Based on recent literature, EAA has been suggested as an intermediate biological mechanism linking environmental exposures (including stress) with poor health outcomes and mortality later in life.

However, most studies investigated older populations, while only a few studies have investigated younger subjects. Based on a sample of middle-aged women, Simons et al. [15] have found an association between income and accelerated aging, that was unaffected by controlling for other SES-related factors (i.e., education, marital status, and childhood adversity). They concluded that chronic financial pressures associated with low income exert a weathering effect that results in premature aging. Using data on age acceleration from the UK Household Longitudinal Study, Hughes et al. [16] confirmed the association of EEA and low SES in early life, but no associations were found with current/adult measures of social position on a sample aged less than 65 years old.

Little is known whether current occupational characteristics or job-related stress - crucial SES characteristics - are associated with EAA. Among the few available studies, a recent study reported an increase in the GrimAge marker, but not in the other two AA markers (DNAm age, PhenoAge), associated with high occupational physical activity [17]. In a US study, performing shift work or night shift work for more than 10 years was associated with an increased EAA PhenoAge marker [10]. Carugno et al. [18], in a study on female nurses, found that night shift work was associated with an increased age acceleration, measured through analysis of five $\mathrm{CpG}$ islands in five genes, but limited to subjects with overweight/obesity or exposed to high work stress.

DNA methylation levels (not EAA) have been associated with stress-related conditions. Based on their systematic review of human and animal studies on work stress, burnout and depression, Bakusic et al. [19] concluded that DNA methylation changes are possible biomarkers of stress-related mental disorders. Among human studies, Duman et al. [20] reported a significant increase in global DNA methylation associated with perceived work stress. In a Finnish study on nurses, hypomethylation of the promoter of the serotonin transporter gene (SLC6A4) was associated with both increased burnout symptoms and perceived work stress when mutually adjusted for [21]. Furthermore, in a Japanese study on manufacturing workers, methylation of most $\mathrm{CpG}$ islands in the tyrosine hydroxylase gene, promoter included, was significantly increased among those exposed to high job strain [22].

There is ample evidence from the literature on work stress that exposure to psychosocial stressors in the workplace, like those measured using work-stress models such as the demand-control [23] and the effortreward-Imbalance [24] model, is associated with clinical biomarkers and adverse outcomes. According to the former, the combination of demands and control defines the job strain; it posits that people working in jobs characterized by high demands and low control are at risk of stress-related ill health and disease. Support to this model comes from studies showing that workers exposed to high strain increased risks of coronary heart disease [23, 24], diabetes [25], atherosclerosis in its early non-symptomatic stages [26], as well as increased levels of brain-derived neurotrophic factor [27]. The effort-reward imbalance model, which stems from the social exchange theory [28], captures an employee dissatisfaction about the perceived imbalance between the reward received, in terms of money, career, recognition and job security, and the effort made that would affect well-being and health-related behaviour. In 2017, a review found that effort-reward imbalance was associated with several biological changes in pathways, leading to stressrelated conditions: including decreased heart rate variability, increased blood lipids, blood pressure and cortisol release, altered immune function, inflammation, increased risk of metabolic syndrome [29]. Furthermore, a large multicohort study found an increased risk of coronary heart disease associated with high effort-reward imbalance [30]. 
In this context, to contribute elucidating potential mechanisms through which life-stressing conditions and job stress may impact health, we investigated the relation of EAA with psychosocial and other work characteristics. In relation to epigenetic clocks, we examined the distribution of work-related stress and well-being indicators in the Northern Finland Birth cohort 1966 (NFBC 1966), adjusting for known risk factors for accelerated ageing.

We analyzed well-known work-related stress indicators such as job strain, effort-reward imbalance and overcommitment, discontinuous work history, excessive working hours, shift work, and other work characteristics, including two indicators of positive occupational psychology: work engagement and work favouring attitude. We evaluated the epigenetic age acceleration using five epigenetic ageing biomarkers: Horvath and Hannum first-generation clocks, Levine DNA methylation PhenoAge and Lu's DNA methylation GrimAge (the last two known as the second-generation clocks), and the newly developed pace of aging biomarker, DunedinPoAm, trained on longitudinal data [1, 6, 31-33].

\section{RESULTS}

\section{Descriptive summary of epigenetic age acceleration and pace of ageing}

Table 1 contains detailed definitions and interpretations of the two work stress indicators and the other work characteristics examined.

Table 2 reports the descriptive statistics for the epigenetic age acceleration markers and the pace of aging at 46 years for the NFBC data. Women represent $55 \%$ of the sample, with a BMI <24.9 for $47 \%$, mainly with a secondary education level (68\%) and moderate alcohol consumption $(81 \%)$, physically very active during leisure time (55\%) and never smoked (53\%). Men show a similar pattern; however, a higher proportion was overweight (46\%). Overall, $87 \%$ had a permanent job contract. A higher proportion of men were unemployed (7.1\%, compared to $4.7 \%$ among women), while women showed a higher percentage in a temporary job $(10 \%$, compared to $3 \%$ among men). We evaluated the association between job exposures and risk factors using Chi-Square test, Student t-test or ANOVA depending on the variable characteristics (categorical or continuous; see Supplementary Table 1 in Supplementary Materials). We found statistically significant association of smoking with effort and effort-reward Imbalance, type of employer (private or state/municipality) and occupational group.

Additionally, we estimated the effect of non-occupational risk factors for aging on the biomarkers (sex, education, smoking habit, alcohol consumption, BMI, physical activity, see Figure 1). We observed higher EAA in men for all but PhenoAge biomarkers, which were positively associated with smoking and BMI. GrimAgeAA and DunedinPoAm also showed a positive association with smoking and BMI and a negative association with physical activity. Pearson correlations among EAA measures (Supplementary Table 2 in Supplementary Materials) show the highest coefficients were found between Horvath and Hannum AA $(\rho=0.96)$ and between GrimAgeAA and DunedinPoAm $(\rho=0.78)$. The remaining pairwise correlations were in the range $0.20-0.48$.

\section{Multivariate models}

Results are reported as estimates and 95\% confidence intervals from linear regression, where EAA is the dependent variable and work characteristics the predictors. The estimates are interpretable as years of increase/decrease for epigenetic age: positive coefficients indicate increased age acceleration and negative coefficients indicate a decrease of the estimated biological age compared to the chronological age. For DunedinPoAm, the effect size indicates the rate of increasing biological aging (in percentage) comparing a group with the reference category. In Supplementary Materials, we have provided the results as standardized coefficients estimates for the adjusted and unadjusted models for each epigenetic biomarker (Supplementary Tables 4, 5 in Supplementary Materials); these results are interpretable with regard of the EEA standard deviations (Table 1).

\section{Horvath and Hannum AA}

The two EEA are highly correlated, so the pattern of exposure to which they are associated are similar. In unadjusted models (Table 3), we have found that being in a temporary versus a permanent job showed a negative association with Horvath age acceleration $(\beta=$ $-1.2895 \% \mathrm{CI}-2.527,-0.034)$, hence slowing aging. Both biomarkers, Horvath and Hannum AA were associated with working for more than 40 hours per week that increased the EAA over 1.5 years, (HorvathAA $\beta$ $=2.058$ 95\%CI 0.517,3.599), HannumAA $\beta=1.567$, $95 \%$ CI $0.415,2.719)$ ) when compared with working less than 31 hours per week. In the adjusted models (Supplementary Table 3 in Supplementary Materials), only good job security remained significant for HorvathAA ( $\beta=1.51195 \% \mathrm{CI}-0.001,3.022)$ HannumAA $(\beta=1.171$ 95\%CI 0.042,2.3).

\section{PhenoAge and GrimaAge AA}

PhenoAgeAA was associated with job strain, active work- compared to reference low strain- in both 
Table 1. Job exposure definitions.

\begin{tabular}{ll}
\hline Concept & Description \\
\hline Job strain & Depicts an individual's experience of a psychosocial work environment that \\
entails a high level of job demands combined with a low level of job control, \\
resulting in job strain. \\
Originally suggested by Karasek in 1979, the demands-control model \\
highlights the role of job control, as not only buffering for stress but resulting \\
in active, healthy work in circumstances where high demands and high control \\
prevail simultaneously. \\
A large body of evidence has linked job strain with excess morbidity and \\
mortality [24, 34, 35] \\
Captures an individual's perception of reciprocity between high effort at work \\
and the actual/expected rewards received in turn. As suggested by Siegrist in \\
1990s, an imbalance between these two, effort not met with sufficient rewards, \\
is considered a source of work stress. \\
ERI has been linked with both cardiovascular and mental health outcomes \\
[29, 36]. \\
An addition to the ERI model. Represents an individual's tendency to put high \\
effort at work even in circumstances of low rewards. Overcommitment is \\
considered a toxic component, increasing the work stress related to ERI. \\
Physical activity in the domain of work, in opposition to leisure-time physical \\
activity. High levels of OPA (lifting, standing, heavy manual work) indicate \\
high physical job demands. \\
OPA may not be associated with good health, in contrast with leisure-time \\
physical activity [37]. \\
Refers to high personal meaning of work as a way to exercise and master skills \\
or even as a calling, as opposed to seeing work merely as a source of income \\
[38]. \\
A concept of positive occupational psychology and work-related well-being \\
[39]. Depicts experience of the following three dimensions at work: vigor, \\
dedication and absorption (flow). \\
Captures an individual's perception of the stability of one's job contract [40]. \\
Work engagement \\
Work-favouring attitude
\end{tabular}

unadjusted $(\beta=-1.201 \quad 95 \% \mathrm{CI} \quad-2.292, \quad-0.11)$ and adjusted $(\beta=-1.30195 \% \mathrm{CI}-2.391,-0.212)$ ) models.

In the unadjusted models, GrimAgeAA was associated with several exposures among which unemployment increase of more than 1.5 years $\beta=1.741(0.347,3.135)$ compared to employed, belonging to the white-collar occupational group decreases the aging of almost 1.5 years $(\beta=-1.447,95 \% \mathrm{CI}-2.127,-0.768)$ and working for the state/municipality as well slowed the aging similarly $(\beta=-1.219,95 \%$ CI -1.885, -0.552). However, upon adjustment, only working as white-collar remained statistically significant a little above six months $(\beta=-0.683,95 \% \mathrm{CI}-1.264,-0.102)$ when compared to blue collars.

\section{Rate of aging: DunedinPoAm}

For the unadjusted fit, we found a statistically significant association for being working as white-collar - $\beta=-0.015,95 \% \mathrm{CI}-0.026,-0.003$ ) compared with being blue-collar. Effort ( $\beta=0.009$, 95\%CI 0.001,0.018) and evening shift increase the rate of aging of less than $2 \%$ $(\beta=0.015, \quad 95 \% \mathrm{CI} \quad 0.001,0.03)$. No statistically significant association was found once we adjusted for all the known risk factors.

\section{Sensitivity analysis: sex-stratified}

Adjusted models were fitted for women and men separately. Among women (Supplementary Table 6 in Supplementary Materials), we found that being in a temporary job versus a permanent one presented a negative association with Horvath age acceleration ( $\beta=-$ 1.484 95\%CI -2.922, -0.047), whereas the estimate obtained for being continuously employed versus discontinuously with GrimAge $(\beta=-0.696,95 \%$ CI $1.309,-0.009)$ decreased the AA.

In contrast to our expectations, higher Effort-Reward Imbalance was associated with a decrease by approximately one year in the AA for both Horvath 
Table 2. Descriptive statistics of the study population, mean and standard deviation (sd) for continuous variables and frequency and percentage for categorical variables.

\begin{tabular}{|c|c|c|c|}
\hline & All N=604 & Females $\mathbf{N}=\mathbf{3 3 7}$ & Males $\mathrm{N}=\mathbf{2 6 7}$ \\
\hline HorvathAA, mean (sd) & $0.0(4.0)$ & $-0.4(3.9)$ & $0.5(4.1)$ \\
\hline HannumAA, mean (sd) & $-0.01(2.99)$ & $-0.32(2.92)$ & $0.39(3.04)$ \\
\hline PhenoAgeAA, mean (sd) & $-0.1(4.8)$ & $0.2(4.8)$ & $-0.5(4.8)$ \\
\hline GrimAgeAA, mean (sd) & $-0.1(4.1)$ & $-0.8(3.9)$ & $0.9(4.1)$ \\
\hline DunedinPoAm, mean (sd) & $1.00(0.07)$ & $1.01(0.07)$ & $1.00(0.07)$ \\
\hline \multicolumn{4}{|l|}{ BMI n $(\%)$} \\
\hline Optimal< 24.9 & $248(41 \%)$ & $158(47 \%)$ & $90(34 \%)$ \\
\hline Overweight 25-29.9 & $232(39 \%)$ & $111(33 \%)$ & $121(46 \%)$ \\
\hline Obese $>=30$ & $118(20 \%)$ & $64(19 \%)$ & $54(20 \%)$ \\
\hline Missing & 6 & 4 & 2 \\
\hline \multicolumn{4}{|l|}{ Educational Level n (\%) } \\
\hline Basic & $28(4.7 \%)$ & $15(4.6 \%)$ & $13(4.9 \%)$ \\
\hline Secondary & $409(69 \%)$ & $221(68 \%)$ & $188(71 \%)$ \\
\hline Tertiary & $154(26 \%)$ & $91(28 \%)$ & $63(24 \%)$ \\
\hline Missing & 13 & 10 & 3 \\
\hline \multicolumn{4}{|l|}{ Alcohol consumption n (\%) } \\
\hline Never & $53(8.8 \%)$ & $35(10 \%)$ & $18(6.7 \%)$ \\
\hline Moderate & $493(82 \%)$ & $273(81 \%)$ & $220(82 \%)$ \\
\hline Heavy & $56(9.3 \%)$ & $27(8.1 \%)$ & $29(11 \%)$ \\
\hline Missing & 2 & 2 & 0 \\
\hline \multicolumn{4}{|l|}{ Smoking n (\%) } \\
\hline Never & $322(53 \%)$ & $199(59 \%)$ & $123(46 \%)$ \\
\hline Past & $155(26 \%)$ & $71(21 \%)$ & $84(31 \%)$ \\
\hline Current & $127(21 \%)$ & $67(20 \%)$ & $60(22 \%)$ \\
\hline \multicolumn{4}{|c|}{ Physical Activity (leisure) n (\%) } \\
\hline Inactive & $145(24 \%)$ & $71(21 \%)$ & $74(28 \%)$ \\
\hline Moderately Active & $124(21 \%)$ & $66(20 \%)$ & $58(22 \%)$ \\
\hline Active/Very Active & $335(55 \%)$ & $200(59 \%)$ & $135(51 \%)$ \\
\hline \multicolumn{4}{|l|}{ Job status n $(\%)$} \\
\hline Permanent & $526(87 \%)$ & $286(85 \%)$ & $240(90 \%)$ \\
\hline Temporary & $43(7.1 \%)$ & $35(10 \%)$ & $8(3.0 \%)$ \\
\hline Unemployed & $35(5.8 \%)$ & $16(4.7 \%)$ & $19(7.1 \%)$ \\
\hline \multicolumn{4}{|l|}{ Employer } \\
\hline private employer & $322(57 \%)$ & $133(42 \%)$ & $189(78 \%)$ \\
\hline state/municipality & $240(43 \%)$ & $186(58 \%)$ & $54(22 \%)$ \\
\hline Missing & 42 & 18 & 24 \\
\hline \multicolumn{4}{|l|}{ Occupational group } \\
\hline White collars & $244(46 \%)$ & $163(55 \%)$ & $129(54 \%)$ \\
\hline Blue collars & $292(54 \%)$ & $135(45 \%)$ & $109(46 \%)$ \\
\hline Missing & 68 & 39 & 29 \\
\hline Job Control mean(sd) & $3.83(0.77)$ & $3.77(0.77)$ & $3.90(0.76)$ \\
\hline Missing & 54 & 31 & 23 \\
\hline Job Demands mean(sd) & $4.21(0.67)$ & $4.31(0.64)$ & $4.07(0.68)$ \\
\hline Missing & 51 & 27 & 24 \\
\hline Job strain Linear & $0.19(0.44)$ & $0.27(0.44)$ & $0.08(0.41)$ \\
\hline Missing & 58 & 33 & 25 \\
\hline \multicolumn{4}{|l|}{ Job strain n (\%) } \\
\hline Active work & $128(23 \%)$ & $97(32 \%)$ & $77(32 \%)$ \\
\hline High strain & $174(32 \%)$ & $93(31 \%)$ & $29(12 \%)$ \\
\hline
\end{tabular}




\begin{tabular}{|c|c|c|c|}
\hline Low strain & $122(22 \%)$ & $53(17 \%)$ & $75(31 \%)$ \\
\hline Passive work & $122(22 \%)$ & $61(20 \%)$ & $61(25 \%)$ \\
\hline Missing & 58 & 33 & 25 \\
\hline Job strain Quotient & $1.14(0.29)$ & $1.19(0.30)$ & $1.08(0.27)$ \\
\hline Missing & 58 & 33 & 25 \\
\hline \multicolumn{4}{|l|}{ Job strain Tertile n (\%) } \\
\hline High strain & $172(32 \%)$ & $131(43 \%)$ & $57(24 \%)$ \\
\hline Intermediate strain & $186(34 \%)$ & $98(32 \%)$ & $88(36 \%)$ \\
\hline Low strain & $188(34 \%)$ & $75(25 \%)$ & $97(40 \%)$ \\
\hline Missing & 58 & 33 & 25 \\
\hline Effort mean(sd) & $2.10(0.67)$ & $2.04(0.67)$ & $2.18(0.66)$ \\
\hline Missing & 48 & 27 & 21 \\
\hline Reward mean(sd) & $2.50(0.55)$ & $2.52(0.54)$ & $2.47(0.55)$ \\
\hline Missing & 63 & 33 & 30 \\
\hline $\begin{array}{l}\text { Effort-Reward Imbalance } \\
\text { mean(sd) }\end{array}$ & $0.90(0.40)$ & $0.87(0.39)$ & $0.94(0.41)$ \\
\hline Missing & 66 & 36 & 30 \\
\hline Overcommitment mean(sd) & $2.10(0.67)$ & $2.93(0.65)$ & $3.05(0.61)$ \\
\hline Missing & 48 & 27 & 28 \\
\hline \multicolumn{4}{|l|}{ Employment history $\mathrm{n}(\%)$} \\
\hline At least temporarily unemployed & $269(45 \%)$ & $157(47 \%)$ & $112(42 \%)$ \\
\hline Continuously employed & $333(55 \%)$ & $178(53 \%)$ & $155(58 \%)$ \\
\hline Missing & 2 & 2 & 0 \\
\hline \multicolumn{4}{|l|}{$\begin{array}{l}\text { Occupational s Physical Activity } \\
\mathrm{n}(\%)\end{array}$} \\
\hline Low Intensity & $421(75 \%)$ & $244(78 \%)$ & $177(72 \%)$ \\
\hline Intermediate Intensity & $68(12 \%)$ & $36(12 \%)$ & $32(13 \%)$ \\
\hline High Intensity & $70(13 \%)$ & $33(11 \%)$ & $37(15 \%)$ \\
\hline Missing & 45 & 24 & 21 \\
\hline \multicolumn{4}{|l|}{ Working Hours per week n $(\%)$} \\
\hline Less than 31 hours & $32(5.7 \%)$ & $24(7.7 \%)$ & $8(3.3 \%)$ \\
\hline $31-40$ hours & $402(72 \%)$ & $244(78 \%)$ & $158(64 \%)$ \\
\hline More than 40 hours & $124(22 \%)$ & $45(14 \%)$ & $79(32 \%)$ \\
\hline Missing & 46 & 24 & 22 \\
\hline \multicolumn{4}{|l|}{ Shifts n $(\%)$} \\
\hline Day job & $446(81 \%)$ & $253(82 \%)$ & $193(79 \%)$ \\
\hline Evening/shift & $108(19 \%)$ & $57(18 \%)$ & $51(21 \%)$ \\
\hline Missing & 50 & 27 & 23 \\
\hline Work attitude mean(sd) & $17.5(3.5)$ & $17.9(3.6)$ & $17.0(3.3)$ \\
\hline Missing & 8 & 6 & 2 \\
\hline Work engagement mean(sd) & $41(10)$ & $42(10)$ & $39(11)$ \\
\hline Missing & 55 & 29 & 26 \\
\hline \multicolumn{4}{|l|}{ Good job security n (\%) } \\
\hline No & $83(15 \%)$ & $45(15 \%)$ & $38(15 \%)$ \\
\hline Yes & $474(85 \%)$ & $266(85 \%)$ & $208(85 \%)$ \\
\hline Missing & 47 & 26 & 21 \\
\hline
\end{tabular}

$(\beta=-1.292, \quad 95 \% \mathrm{CI}-2.486,-0.099)$ and Hannum markers $(\beta=-0.915,95 \% \mathrm{CI}-1.812,-0.019)$. It is worth underlying that if the effort-reward imbalance has a value below or close to zero, it indicates a favourable condition (low effort, high reward), whereas values above 1.0 indicate exposure to work stress, according to the model.
Long working hours and strenuous occupational physical activity (OPA) increased the AA of these markers by more than 2 years: for working more than 40 hours/week versus $<31$ hours/week we observed increases in Horvath AA $(\beta=2.075,95 \%$ CI 0.534 , 3.616) and Hannum AA $(\beta=2.483$, 95\%CI 0.421 , 4.546 ), and for high-intensity strenuous physical effort 
and increase in Hannum AA $\quad(\beta=1.248$ 95\%CI $0.088,2408)$.

For men (Supplementary Table 7 in Supplementary Materials), DunedinPoAm showed a decreased rate in job demand $(\beta=-0.012,95 \%$ CI $-0.023,-0.001)$, but no effect was found for job control. An increase was observed for evening jobs compared with day ones $(\beta=0.021,95 \% \mathrm{CI}$ $0.002,0.039)$. Nevertheless, unlike observed among women, no significant effects were found for working hours in any of the outcomes analyzed.

Occupational physical activity seems to be beneficial in men, where high-intensity strenuous physical effort decreases AA for Horvath ( $\beta=-1.775,95 \%$ CI -3.282 , $0.267)$ and Hannum $(\beta=-1.22,95 \%$ CI $-2.348,-0.092)$ with an opposite effect for GrimaAge in intermediate intensity $(\beta=1.65195 \% \mathrm{CI} 0.4,2.901)$. GrimAge was also negatively associated with white-collar occupational class $(\beta=-1.245,95 \% \mathrm{CI}-2.164,-0.325)$. Lack of job security increased by more than one year the Hannum marker ( $\beta=1.132,95 \%$ CI 2.191, 0.072), although it was expected to capture a stressful condition.
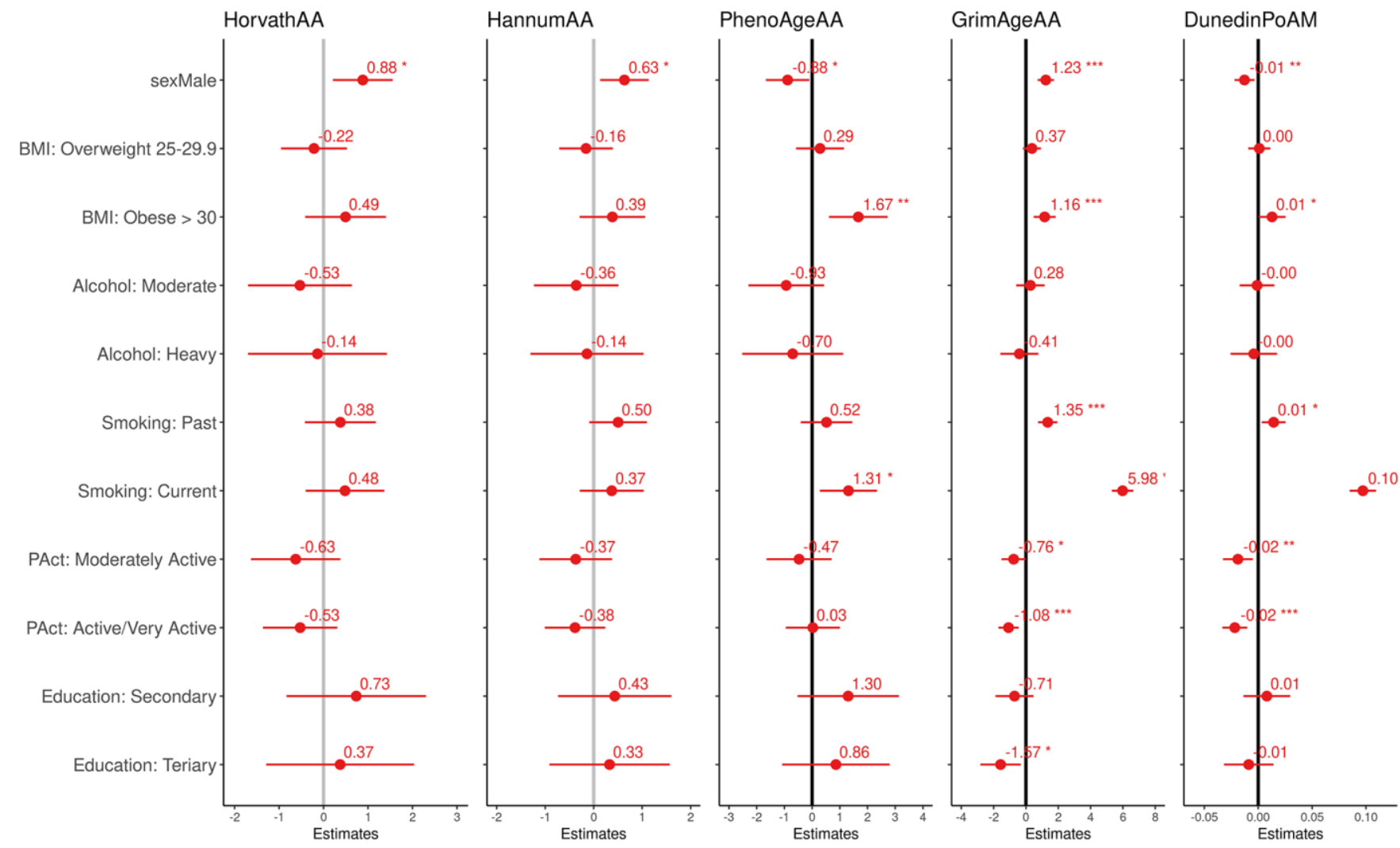

Figure 1. Effect size and $95 \%$ confidence intervals (interpretable as years of increase/decreasing epigenetic age and rate of aging) of the association between the four epigenetic aging biomarkers and the pace of aging and modifiable risk factor. 
Table 3. Unadjusted coefficient estimates form linear regression with $95 \%$ confidence intervals.

\begin{tabular}{|c|c|c|c|c|c|c|}
\hline & & HorvathAA & HannumAA & PhenoAgeAA & GrimAgeAA & DunedinPoAm \\
\hline & & $\begin{array}{c}\text { Estimates }(95 \% \\
\text { CI) }\end{array}$ & $\begin{array}{l}\text { Estimates } \\
(95 \% \mathrm{CI})\end{array}$ & $\begin{array}{c}\text { Estimates }(95 \% \\
\text { CI })\end{array}$ & $\begin{array}{c}\text { Estimates }(95 \% \\
\text { CI) }\end{array}$ & $\begin{array}{c}\text { Estimates (95\% } \\
\text { CI) } \\
\end{array}$ \\
\hline \multirow{2}{*}{ Job Status } & permanent & Ref. & Ref. & Ref. & Ref. & Ref. \\
\hline & unemployed & $\begin{array}{c}0.21 \\
(-1.161,1.582)\end{array}$ & $\begin{array}{c}0.105 \\
(-0.92,1.129)\end{array}$ & $\begin{array}{c}0.895 \\
(-0.752,2.543)\end{array}$ & $\begin{array}{c}1.741 \\
(0.347,3.135) *\end{array}$ & $\begin{array}{c}0.019 \\
(-0.005,0.043)\end{array}$ \\
\hline Employer & state/municipality & $\begin{array}{c}-0.34 \\
(-1.012,0.333)\end{array}$ & $\begin{array}{c}-0.253 \\
(-0.756,0.249)\end{array}$ & $\begin{array}{c}0.187 \\
(-0.62,0.994)\end{array}$ & $\begin{array}{c}-1.219 \\
(-1.885,-0.552) *\end{array}$ & $\begin{array}{c}-0.006 \\
(-0.017,0.006)\end{array}$ \\
\hline \multirow{2}{*}{$\begin{array}{l}\text { Occupational } \\
\text { group }\end{array}$} & Blue collars & Ref. & Ref. & Ref. & Ref. & Ref. \\
\hline & White collars & $\begin{array}{c}0.136 \\
(-0.55,0.822)\end{array}$ & $\begin{array}{c}0.088 \\
(-0.425,0.602)\end{array}$ & $\begin{array}{c}0.006 \\
(-0.816,0.828)\end{array}$ & $\begin{array}{c}-1.447 \\
(-2.127,-0.768) *\end{array}$ & $\begin{array}{c}-0.015 \\
(-0.026,-0.003) \text { * }\end{array}$ \\
\hline Job strain Linear & & $\begin{array}{c}-0.488 \\
(-1.257,0.281)\end{array}$ & $\begin{array}{c}-0.27(- \\
0.845,0.305)\end{array}$ & $\begin{array}{c}-0.095 \\
(-1.014,0.823)\end{array}$ & $\begin{array}{c}-0.153 \\
(-0.921,0.615)\end{array}$ & $\begin{array}{c}0 \\
(-0.014,0.013)\end{array}$ \\
\hline \multirow{4}{*}{ Job strain } & Low strain & Ref. & Ref. & Ref. & Ref. & Ref. \\
\hline & active work & $\begin{array}{c}0.151 \\
(-0.767,1.069)\end{array}$ & $\begin{array}{c}0.169 \\
(-0.517,0.855)\end{array}$ & $\begin{array}{c}-1.201 \\
(-2.292,-0.11) *\end{array}$ & $\begin{array}{c}-0.342 \\
(-1.258,0.573)\end{array}$ & $\begin{array}{c}-0.008 \\
(-0.024,0.008)\end{array}$ \\
\hline & passive work & $\begin{array}{c}0.112 \\
(-0.886,1.109)\end{array}$ & $\begin{array}{c}0.139 \\
(-0.606,0.884)\end{array}$ & $\begin{array}{c}-0.685 \\
(-1.871,0.501)\end{array}$ & $\begin{array}{c}0.21(- \\
0.784,1.205)\end{array}$ & $\begin{array}{c}0.004 \\
(-0.013,0.021)\end{array}$ \\
\hline & high strain & $\begin{array}{c}-0.355 \\
(-1.353,0.643)\end{array}$ & $\begin{array}{c}-0.225 \\
(-0.971,0.52)\end{array}$ & $\begin{array}{c}-0.262 \\
(-1.448,0.924)\end{array}$ & $\begin{array}{c}0.016 \\
(-0.979,1.011)\end{array}$ & $\begin{array}{c}0.005 \\
(-0.012,0.022)\end{array}$ \\
\hline $\begin{array}{l}\text { Job strain } \\
\text { quotient }\end{array}$ & & $\begin{array}{c}-0.938 \\
(-2.087,0.211)\end{array}$ & $\begin{array}{c}-0.557 \\
(-1.417,0.302)\end{array}$ & $\begin{array}{c}-0.232 \\
(-1.606,1.143)\end{array}$ & $\begin{array}{c}0.059 \\
(-1.09,1.208)\end{array}$ & $\begin{array}{c}0.001 \\
(-0.019,0.021)\end{array}$ \\
\hline Reward & & $\begin{array}{c}0.087 \\
(-0.53,0.704)\end{array}$ & $\begin{array}{c}0.177 \\
(-0.284,0.639)\end{array}$ & $\begin{array}{c}0.237 \\
(-0.505,0.979)\end{array}$ & $\begin{array}{c}0.327 \\
(-0.292,0.946)\end{array}$ & $\begin{array}{c}0.002 \\
(-0.009,0.013)\end{array}$ \\
\hline $\begin{array}{l}\text { Effort-Reward } \\
\text { Imbalance }\end{array}$ & & $\begin{array}{c}-0.524 \\
(-1.365,0.318)\end{array}$ & $\begin{array}{c}-0.451 \\
(-1.08,0.178)\end{array}$ & $\begin{array}{c}-0.396 \\
(-1.411,0.619)\end{array}$ & $\begin{array}{c}0.795 \\
(-0.05,1.639)\end{array}$ & $\begin{array}{c}0.011 \\
(-0.003,0.026)\end{array}$ \\
\hline Overcommitment & & $\begin{array}{c}0.171 \\
(-0.353,0.694)\end{array}$ & $\begin{array}{c}0.102 \\
(-0.29,0.494)\end{array}$ & $\begin{array}{c}0.131 \\
(-0.498,0.76)\end{array}$ & $\begin{array}{c}0.148 \\
(-0.384,0.68)\end{array}$ & $\begin{array}{c}0 \\
(-0.009,0.009)\end{array}$ \\
\hline \multirow[t]{2}{*}{ Work history } & $\begin{array}{c}\text { At least } \\
\text { temporary } \\
\text { unemployed }\end{array}$ & Ref. & Ref. & Ref. & Ref. & Ref. \\
\hline & $\begin{array}{l}\text { Continuously } \\
\text { Employed }\end{array}$ & $\begin{array}{c}0.236 \\
(-0.41,0.882)\end{array}$ & $\begin{array}{c}0.238 \\
(-0.244,0.72)\end{array}$ & $\begin{array}{c}-0.11 \\
(-0.883,0.662)\end{array}$ & $\begin{array}{c}-0.665 \\
(-1.321,-0.008) *\end{array}$ & $\begin{array}{c}-0.01 \\
(-0.021,0.001)\end{array}$ \\
\hline \multirow{3}{*}{$\begin{array}{l}\text { Occupational } \\
\text { Physical Activity }\end{array}$} & Low Intensity & Ref. & Ref. & Ref. & Ref. & Ref. \\
\hline & $\begin{array}{l}\text { Intermediate } \\
\text { Intensity }\end{array}$ & $\begin{array}{c}-0.282 \\
(-1.304,0.74)\end{array}$ & $\begin{array}{c}-0.149 \\
(-0.913,0.615)\end{array}$ & $\begin{array}{c}0.446 \\
(-0.787,1.679)\end{array}$ & $\begin{array}{c}1.369 \\
(0.342,2.395) *\end{array}$ & $\begin{array}{c}0.013 \\
(-0.005,0.031)\end{array}$ \\
\hline & High Intensity & $\begin{array}{c}0.066 \\
(-0.944,1.076)\end{array}$ & $\begin{array}{c}0.158 \\
(-0.597,0.913)\end{array}$ & $\begin{array}{c}0.753 \\
(-0.465,1.971)\end{array}$ & $\begin{array}{c}0.68 \\
(-0.334,1.693)\end{array}$ & $\begin{array}{c}-0.003 \\
(-0.021,0.014)\end{array}$ \\
\hline \multirow{2}{*}{$\begin{array}{l}\text { Working hours } \\
\text { per week }\end{array}$} & $\begin{array}{l}\text { less than } 31 \\
\text { hours }\end{array}$ & Ref. & Ref. & Ref. & Ref. & Ref. \\
\hline & 31-40 hours & $\begin{array}{c}1.247 \\
(-0.181,2.675)\end{array}$ & $\begin{array}{c}0.959 \\
(-0.108,2.026)\end{array}$ & $\begin{array}{c}-0.521 \\
(-2.254,1.213)\end{array}$ & $\begin{array}{c}0.044 \\
(-1.407,1.495)\end{array}$ & $\begin{array}{c}-0.002 \\
(-0.027,0.024)\end{array}$ \\
\hline
\end{tabular}




\begin{tabular}{|c|c|c|c|c|c|c|}
\hline & $\begin{array}{c}\text { more than } 40 \\
\text { hours }\end{array}$ & $\begin{array}{c}2.058 \\
(0.517,3.599) *\end{array}$ & $\begin{array}{c}1.567 \\
(0.415,2.719) *\end{array}$ & $\begin{array}{c}0.085 \\
(-1.786,1.956)\end{array}$ & $\begin{array}{c}0.573(- \\
0.994,2.139)\end{array}$ & $\begin{array}{c}0.001 \\
(-0.026,0.028)\end{array}$ \\
\hline \multirow[t]{2}{*}{ Working shift } & Day job & Ref. & Ref. & Ref. & Ref. & Ref. \\
\hline & Evening/shift & $\begin{array}{c}0.455 \\
(-0.383,1.293)\end{array}$ & $\begin{array}{c}0.391 \\
(-0.236,1.019)\end{array}$ & $\begin{array}{c}0.585 \\
(-0.428,1.598)\end{array}$ & $\begin{array}{c}0.733 \\
(-0.114,1.58)\end{array}$ & $\begin{array}{c}0.015 \\
(0.001,0.03) *\end{array}$ \\
\hline Work attitude & & $\begin{array}{c}-0.004 \\
(-0.097,0.089)\end{array}$ & $\begin{array}{c}-0.01 \\
(-0.079,0.059)\end{array}$ & $\begin{array}{c}-0.006 \\
(-0.117,0.105)\end{array}$ & $\begin{array}{c}-0.041(- \\
0.135,0.052)\end{array}$ & $\begin{array}{c}-0.001 \\
(-0.003,0.001)\end{array}$ \\
\hline $\begin{array}{l}\text { Work } \\
\text { engagement }\end{array}$ & & $\begin{array}{c}0.005 \\
(-0.028,0.037)\end{array}$ & $\begin{array}{c}0.003 \\
(-0.021,0.028)\end{array}$ & $\begin{array}{c}0.009 \\
(-0.03,0.049)\end{array}$ & $\begin{array}{c}-0.049(-0.081,- \\
0.016) *\end{array}$ & $\begin{array}{c}-0.001 \\
(-0.001,0)\end{array}$ \\
\hline \multirow[t]{2}{*}{$\begin{array}{l}\text { Good job } \\
\text { security }\end{array}$} & No & Ref. & Ref. & Ref. & Ref. & Ref. \\
\hline & Yes & $\begin{array}{c}1.016 \\
(0.089,1.944) *\end{array}$ & $\begin{array}{c}0.778 \\
(0.084,1.471) *\end{array}$ & $\begin{array}{c}0.872 \\
(-0.251,1.996)\end{array}$ & $\begin{array}{c}-0.11 \\
(-1.052,0.831)\end{array}$ & $\begin{array}{c}-0.005 \\
(-0.021,0.011)\end{array}$ \\
\hline
\end{tabular}

effort-reward imbalance, although for the latter two differences were not significant. The other biomarkers were statistically significantly associated for job strain (decelerated epigenetic aging in active workers) for PhenoAgeAA and job category (decelerated EEA in white collars compared with blue collars in GrimAgeAA).

Once we stratified analyses by sex, a different pattern of association emerged, with women leading on the statistically significant results. Although job strain was overall not significantly associated with EAA, for some aging biomarkers, the effect size for women and men were in opposite directions. For example, in GrimAgeAA, women showed an accelerating effect for job demands and consequently for two job strain formulations. Among women, effort and effort-reward imbalance presented a less accelerating effect when compared with men, and the same pattern was detected with overcommitment for all the outcomes.

Long working hours(>55hours/week) and shift work have been associated with increased risk of chronic conditions like stroke or breast cancer [41, 42], and working long hours is a risk factor for shortened sleeping hours and difficulty falling asleep [43]. A Japanese study conducted among white-collar factory workers found that long working hours lead to sleep problems in a dose-response manner and impeded adequate recovery from fatigue, resulting in cumulative fatigue [44]. A previous study [45] found that men working long hours showed a worse cardiometabolic and inflammatory profile and increased anthropometric markers compared to those who did not work long hours; this was not confirmed in women, where these relations were absent or weak. Our study found that women have an increase of age acceleration over two years for Hannum and Horvath AA, when working for more than 40 hours/week. While we are not able to understand the biological mechanism, a study in UK found that among women working long hours and weekends deteriorates their mental health and increases depressive symptoms [46]. We hypothesize that mental health is acting as a mediator between the long hours of work and age acceleration, as findings of association between depression and AA start to emerge $[47,48]$.

High-intensity physical effort at work had an increasing effect for women but a decreasing effect in men. This contrasting result in men and women seems to point to the idea that the effects of job stress are different in the two genders [49], with women being affected more at an emotional level. While our intention was not to assess gender differences, nor we detect any substantial pattern in this sense, other fields such as occupational psychology [50] have assessed differences in work stress management. It has been observed that women express greater psychosomatic complaints when working in high demand, low control, and low support settings than their males [50]. While we have no evidence from our data, the increased effect in OPA seen for women might also be related to the heavy features of their jobs that like cleaning or nursing.

The effort-reward imbalance that represents "the interaction between a person's cognitions, emotions, and behaviours, and the material and social work context" decreased the AA for both Horvath and Hannum markers in both genders, although significantly only among women. This seems in contrast with results from another study suggesting that women who experienced a higher level of reward showed more positive health functioning. This might be because women seem to experience a higher buffering effect from social support than from job control. Likewise, a recent study [51] conducted on the German socio-economic panel data, reported higher values for men in 'effort' and effort-reward ratio but no significant gender differences for the 
association between effort-reward imbalance model and the risk of self-reported depression.

Different epigenetic age acceleration indicators seem to represent different aspects of aging. HannumAA has been described as a biomarker of immune system ageing and demonstrated sensitivity to variations in the environment and lifestyle. At the same time, HorvathAA is a stable indicator of metabolic aging processes [52]. However, we have found that HorvathAA and HannumAA indicators are highly correlated, as reported by Lau et al. [53], in contrast with others who reported low correlation values [54]. Our results confirmed that the GrimAge clock is higher in smokers (past and current) and in relation to alcohol intake, as also found by Kresovich et al. [54]; in fact, the clock is constructed as the composite of 8 DNA methylation-based markers for plasma proteins and selfreported smoking packs [32] making it more responsive to smokers. Differences by gender were statistically significant for all AA markers, but female gender was positively associated with Horvath, Hannum and GrimAge, and negatively associated with PhenoAge and DunedinPoAm. This points to the observed difference between women and men, who present a diverse pattern in terms of epigenetics [49-51], which was the main reason to add, despite the small sample size, the sex-stratified analysis. Singmann et al. [55] have identified and validated $1,184 \mathrm{CpG}$ sites to be differentially methylated between men and women; for these $\mathrm{CpGs}$ there is large overlap with the $\mathrm{CpG}$ sites used to define the EEAA. For Hannum the overlap is $28 \%$, for Horvath $17 \%$, for PhenoAge $14 \%$, and for DunedinPoAm is $76 \%$. However, the pace of aging is the indicator that discriminates less across variables.

Lastly, we observed that adjusted associations for the biomarkers with known risk factors are mostly not associated, except for smoking levels in GriamAgeAA and DunedinPoAm. While others have found similar pattern, for example, in Fiorito et al. [9], the effect size of the association of BMI, alcohol consumption, and physical activity was less than one-year comparing extreme categories and similar results have been obtained [56, 57].

This paper is one of the first attempts to address the working dimension of epigenetic age acceleration indicators, to the best of our knowledge. The NFBC 1966 cohort at the age of 46 years offers a rich questionnaire that allows studying a general population-based sample representing all occupations and sectors of economy which makes it an ideal setting of studying employmentrelated factors in relation to other health predictors. With this study population, where all the participants were born in the same year in the same geographical region, we minimized confounding by changes in working life circumstances along with macroeconomic trends. In other studies [9], the participants usually have different ages, geographical backgrounds, and working life exposures. As pointed out by Belsky et al. [33], the four age acceleration indicators were developed on blood DNA methylation, making them highly sensitive to changes in chronological age. The drawback is that '...clocks confound methylation patterns arising from early-life exposures to methylation-altering factors with methylation patterns related to biological ageing during adulthood' [33].

There are some limitations in this study. The limited sample size of subjects with both DNA methylation data and job variables affected the regression analysis. It could explain the lack of power in identifying robust work-stress associations, as also did the low Cronbach alpha for overcommitment and reward. Although the questionnaire is detailed on work-related factors, established work stress-related scales, details on job typologies, duration of the work stress or financial job insecurity have not been specifically investigated. Job strain was queried on a reduced number of items from the original Job Content Questionnaire [58], accounting for 42 items. Furthermore, due to the small sample size, other work-related indicators have been collapsed in binary variables, implying low variability.

The subjects in NFBC are mostly permanently occupied, with little worries about job security as $85 \%$ rated their job as secure. $77 \%$ worked less than or up to 40 hours per week and in a diurnal job with no shifts. Overall, the sample is homogenous, and stems from a Nordic welfare society with rather favourable working conditions and women participating in working life equally often as men, although the distribution of occupations is quite gendered as in most societies - women predominate nursing, men construction etc. Nevertheless, the characteristics of the NFBC dataset could be the reason for the inconsistent results observed. In a previous study conducted on the NFBC data $(n=6496)$ Ek et al. [38] evaluated the employment trajectories over 30 years (ages 16 to 45), derived by latent class analysis of retrospective employment history calendars. It emerged that the employment trajectories most favourable for work-related well-being in midlife were rooted in social investments during early life and characterized by attainment of higher education and self-employment.

Nonetheless, this is one of the first studies to quantify the relation between a large variety of job-related variables and epigenetic age acceleration and pace of ageing. Our results suggest that women and men present different associations with different epigenetic distributions regarding work-related stress indicators. 
We advocate for further studies to be carried out for detailed patterns in different types of jobs [59] and in different societies as well as using measurements that target the longitudinal effects of the work environment and employment histories on stress and health and that account for gender differences.

\section{MATERIALS AND METHODS}

\section{Study population}

The study sample consisted of 604 participants from the ongoing Northern Finland Birth Cohort 1966 (NFBC), a longitudinal research program established to promote population-level health and well-being. The NFBC was started as a cohort of mothers and newborns with expected date in 1966 in the provinces of Oulu and Lapland (Finland), including over 95\% of births in the region. The initial aim was to examine the risk factors in preterm birth and the consequences of adverse outcomes and subsequent morbidity. Later on, data were collected at $1,14,31$ and 46 years old through clinical examination, questionnaires (lifestyle, employment and working conditions), and national records to improve population health and well-being [60,61]. From the 46 years old questionnaires, we selected participants belonging to the work force [employed (part-time, full time, self-employed) and unemployed subjects] for which DNA methylation data [62] were available (a random sample), as shown in the flowchart (see Supplementary Figure 1 in Supplementary Materials).

\section{Computation of epigenetic clock measures}

We have calculated four epigenetic age indicators: Horvath [1] DNAm age based on the weighted average of 353 age-related CpG; Hannum [6] DNAm age based on 71 blood specific age-related CpGs; Pheno [63] DNAm age based on 513 phenotypic age-related CpGs and DNAm GrimAge [32].

Based on these epigenetic clocks we defined the extrinsic epigenetic age acceleration (EAA), as the primary outcome, obtained from the residual values of the linear regression of epigenetic age on chronological age. Positive values of EAA indicated faster biological aging, while negative values indicated decelerated aging.

This four EAAs measure how much ageing has occurred in an individual up to the point of measurement. To assess how fast the subject is ageing, we included DunedinPoAm [33] an indicator based on 46 CpGs that is trained on longitudinal data and express a rate of biological aging (compared with the Dunedin sample on which the measure was trained).

\section{Work-related indicators}

We used questionnaire items at age 46 years to obtain the participants' job characteristics, employment history, and work-related stress and well-being indicators (see Table 1 for definitions). We included the current employment status as permanent, temporary, and unemployed. The employer as 'state/municipality' or 'private employer' and the occupational group in two levels: 'blue collars' (service, sale staff, care staff, farmers, building, repairs, transport workers) and 'white collars' (directors, senior management, advisors and official's office workers and customer service).

Indicating work-related stress, Job strain [58] was included as a linear term, as the quotient of demands over control and as categorical at three (low, intermediate, and high strain) and four levels (high strain, active, passive, low strain) reference. As another work stress measure, effort-reward imbalance (ERI) [64] was computed as means of reward and effort scales and as a means ratio (effort/reward). Furthermore, overcommitment was the sum of six items of questions that investigated the extent of excessive investment to work.

We included strenuousness of occupational physical activity (OPA) (low, moderate, and high intensity) and employment history (Continuously vs discontinuously employed); excessive working hours and shift (less than 31 hours per week, 31-40 hours, and more than 40 hours) and when working hours occurred as shift by splitting the answers between 'day job (06-18)' and 'evening/night job'.

Regarding work-related well-being, we collected work favouring attitude as the sum of five items from Kahn and Wiener [65]; and work engagement using the Utrecht Work Engagement Scale [66]. Good job security (yes/no) was collected. Details on the definition of work-related indicators and their Cronbach Alpha are in Supplementary Materials.

\section{Covariates}

As additional variables, we have included established lifestyle-related risk factors for poor health and accelerated ageing. Smoking was classified as: never, past and current smoker. Alcohol consumption was categorized as a non-drinker, moderate or heavy drinker, based on questions on how often and what type of drinks (wine, spirits, beer/cider).

Body Mass Index (BMI) is presented in three levels (optimal $<24.9$, overweight $25-29.9$, obese $>=30$ ); the educational level was classified as basic $(<9$ years of school and no vocational education or only short 
course), secondary (vocational school or college degree and/or matriculation examination) or tertiary (polytechnic or university degree) [67]. Leisure-time physical (LPA) activity has been derived by a combination of questions that accounted for the type of activity (brisk/light) and duration and weekly frequency and summarised in three levels: inactive, moderately active, and very active/active [68]. Age was excluded because chronological age has zero correlation with age acceleration measures (by definition) and we defined sex from birth records.

\section{Statistical methods}

We computed the descriptive statistics (mean and standard deviation) for all the continuous variables and frequency for categorical variables and the Pearson correlation for the four EEAA measures and DunedinPoAm. To evaluate the association of the epigenetic clocks and DunedinPoAm with job measures, we evaluated the association using the ChiSquare test for categorical exposure, Student t-test or Analysis of variance for continuous ones. Initially, to assess the effect of risk factors on the biomarkers, we fitted linear regression models for all the outcomes. Further linear models were fitted for unadjusted and fully adjusted for sex, alcohol consumption, smoking, BMI, educational levels, and physical activity. As a sensitivity analysis, we investigated fully adjusted models separated by sex. Results are reported as estimates, and $95 \%$ confidence intervals and as standardized estimates. Linear regression assumptions were assessed on residual.

\section{Compliance with ethical standards}

All participants gave written informed consent in accordance with the Declaration of Helsinki 1975, as revised in 2000, at each stage of the study. The Ethics Committee approved the study of the Northern Ostrobothnia Hospital District.

\section{Data availability}

NFBC data is available from the University of Oulu, Infrastructure for Population Studies. Permission to use the data can be applied for research purposes via electronic material request portal. In the use of data, we follow the EU general data protection regulation (679/2016) and Finnish Data Protection Act. The use of personal data is based on cohort participant's written informed consent at his/her latest follow-up study, which may cause limitations to its use. Please, contact NFBC project center (NFBCprojectcenter@oulu.fi) and visit the cohort website (http://www.oulu.fi/nfbc) for more information.

\section{AUTHOR CONTRIBUTIONS}

AFS drafted the paper and carried out the statistical analysis. GF and OR provided the epigenetic age. ADE, MV, LAM, MRJ provided input in the study design including the construction of indicators of work exposures and features. JR carried DNA analysis for NFBC. PV was the PI of the study. All authors have read and contributed to the final paper.

\section{ACKNOWLEDGMENTS}

We thank all cohort members and researchers who participated in the 46 years study. We also wish to acknowledge the work of the NFBC project center.

\section{CONFLICTS OF INTEREST}

The authors declare that they have no conflicts of interest.

\section{FUNDING}

This work has been funded by the Colt Foundation with a grant to Paolo Vineis (Project: CF/03/18: Are unstable jobs such as the growing "gig economy" associated with biological age acceleration?"). NFBC1966 received financial support from University of Oulu Grant no. 24000692, Oulu University Hospital Grant no. 24301140, ERDF European Regional Development Fund Grant no. 539/2010 A31592. OR was supported by a UKRI Future Leaders Fellowship (MR/S03532X/1).

\section{REFERENCES}

1. Horvath S. DNA methylation age of human tissues and cell types. Genome Biol. 2013; 14:R115. https://doi.org/10.1186/gb-2013-14-10-r115 PMID:24138928

2. Tan Q. Epigenetic age acceleration as an effective predictor of diseases and mortality in the elderly. EBioMedicine. 2021; 63:103174. https://doi.org/10.1016/i.ebiom.2020.103174 PMID:33340996

3. Vineis $P$, Avendano-Pabon $M$, Barros $H$, Bartley $M$, Carmeli C, Carra L, Chadeau-Hyam M, Costa G, Delpierre C, D'Errico A, Fraga S, Giles G, Goldberg M, et al. Special Report: The Biology of Inequalities in Health: The Lifepath Consortium. Front Public Health. 2020; 8:118. https://doi.org/10.3389/fpubh.2020.00118 PMID: $\underline{2478023}$

4. Palma-Gudiel H, Fañanás L, Horvath $S$, Zannas AS. Psychosocial stress and epigenetic aging. Int Rev Neurobiol. 2020; 150:107-28. 
https://doi.org/10.1016/bs.irn.2019.10.020 PMID:32204828

5. Oblak L, van der Zaag J, Higgins-Chen AT, Levine ME, Boks MP. A systematic review of biological, social and environmental factors associated with epigenetic clock acceleration. Ageing Res Rev. 2021; 69:101348.

https://doi.org/10.1016/j.arr.2021.101348 PMID:33930583

6. Hannum G, Guinney J, Zhao L, Zhang L, Hughes G, Sadda S, Klotzle B, Bibikova M, Fan JB, Gao Y, Deconde $R$, Chen $M$, Rajapakse I, et al. Genome-wide methylation profiles reveal quantitative views of human aging rates. Mol Cell. 2013; 49:359-67. https://doi.org/10.1016/j.molcel.2012.10.016 PMID:23177740

7. Robinson O, Chadeau Hyam M, Karaman I, Climaco Pinto R, Ala-Korpela M, Handakas E, Fiorito G, Gao H, Heard A, Jarvelin MR, Lewis M, Pazoki R, Polidoro S, et al. Determinants of accelerated metabolomic and epigenetic aging in a UK cohort. Aging Cell. 2020; 19:e13149.

https://doi.org/10.1111/acel.13149 PMID:32363781

8. McCrory C, Fiorito G, Hernandez B, Polidoro S, O'Halloran AM, Hever A, NiCheallaigh C, Lu AT, Horvath $S$, Vineis P. Association of 4 epigenetic clocks with measures of functional health, cognition, and all-cause mortality in The Irish Longitudinal Study on Ageing (TILDA). bioRxiv. 2020.

https://doi.org/10.1101/2020.04.27.063164

9. Fiorito G, McCrory C, Robinson O, Carmeli C, OchoaRosales C, Zhang Y, Colicino E, Dugué PA, Artaud F, McKay GJ, Jeong A, Mishra PP, Nøst TH, et al, and BIOS Consortium, and Lifepath consortium. Socioeconomic position, lifestyle habits and biomarkers of epigenetic aging: a multi-cohort analysis. Aging (Albany NY). 2019; 11:2045-70.

https://doi.org/10.18632/aging.101900

PMID: $\underline{31009935}$

10. White AJ, Kresovich JK, Xu Z, Sandler DP, Taylor JA. Shift work, DNA methylation and epigenetic age. Int J Epidemiol. 2019; 48:1536-44.

https://doi.org/10.1093/ije/dyz027 PMID:30879037

11. McCrory C, Fiorito G, Ni Cheallaigh C, Polidoro S, Karisola P, Alenius H, Layte R, Seeman T, Vineis P, Kenny RA. How does socio-economic position (SEP) get biologically embedded? A comparison of allostatic load and the epigenetic clock(s). Psychoneuroendocrinology. 2019; 104:64-73.

https://doi.org/10.1016/j.psyneuen.2019.02.018 PMID:30818253

12. Lawrence KG, Kresovich JK, O'Brien KM, Hoang TT, Xu Z, Taylor JA, Sandler DP. Association of Neighborhood
Deprivation With Epigenetic Aging Using 4 Clock Metrics. JAMA Netw Open. 2020; 3:e2024329.

https://doi.org/10.1001/jamanetworkopen.2020.24329 PMID:33146735

13. McGuinness D, McGlynn LM, Johnson PC, Maclntyre A, Batty GD, Burns H, Cavanagh J, Deans KA, Ford I, McConnachie A, McGinty A, McLean JS, Millar K, et al. Socio-economic status is associated with epigenetic differences in the pSoBid cohort. Int J Epidemiol. 2012; 41:151-60.

https://doi.org/10.1093/ije/dyr215

PMID:22253320

14. Fiorito $G$, Polidoro $S$, Dugué $P A$, Kivimaki $M$, Ponzi $E$, Matullo G, Guarrera S, Assumma MB, Georgiadis P, Kyrtopoulos SA, Krogh V, Palli D, Panico S, et al. Social adversity and epigenetic aging: a multi-cohort study on socioeconomic differences in peripheral blood DNA methylation. Sci Rep. 2017; 7:16266.

https://doi.org/10.1038/s41598-017-16391-5 PMID:29176660

15. Simons RL, Lei MK, Beach SR, Philibert RA, Cutrona CE, Gibbons FX, Barr A. Economic hardship and biological weathering: The epigenetics of aging in a U.S. sample of black women. Soc Sci Med. 2016; 150:192-200. https://doi.org/10.1016/i.socscimed.2015.12.001 PMID:26765221

16. Hughes A, Smart M, Gorrie-Stone T, Hannon E, Mill J, Bao Y, Burrage J, Schalkwyk L, Kumari M. Socioeconomic Position and DNA Methylation Age Acceleration Across the Life Course. Am J Epidemiol. 2018; 187:2346-54. https://doi.org/10.1093/aje/kwy155 PMID: 30060108

17. Kankaanpää A, Tolvanen A, Bollepalli $S$, Leskinen $T$, Kujala UM, Kaprio J, Ollikainen M, Sillanpää E. LeisureTime and Occupational Physical Activity Associates Differently with Epigenetic Aging. Med Sci Sports Exerc. 2021; 53:487-95. https://doi.org/10.1249/MSS.0000000000002498 PMID:32868581

18. Carugno M, Maggioni C, Ruggiero V, Crespi E, Monti $P$, Ferrari L, Pesatori AC. Can Night Shift Work Affect Biological Age? Hints from a Cross-Sectional Study on Hospital Female Nurses. Int J Environ Res Public Health. 2021; 18:10639. https://doi.org/10.3390/ijerph182010639 PMID:34682384

19. Bakusic J, Schaufeli W, Claes S, Godderis L. Stress, burnout and depression: A systematic review on DNA methylation mechanisms. J Psychosom Res. 2017; 92:34-44.

https://doi.org/10.1016/i.jpsychores.2016.11.005 PMID:27998510 
20. Duman EA, Canli T. Influence of life stress, 5-HTTLPR genotype, and SLC6A4 methylation on gene expression and stress response in healthy Caucasian males. Biol Mood Anxiety Disord. 2015; 5:2.

https://doi.org/10.1186/s13587-015-0017-x PMID:25995833

21. Alasaari JS, Lagus $M$, Ollila HM, Toivola A, Kivimäki $M$, Vahtera J, Kronholm E, Härmä M, Puttonen S, Paunio T. Environmental stress affects DNA methylation of a CpG rich promoter region of serotonin transporter gene in a nurse cohort. PLoS One. 2012; 7:e45813.

https://doi.org/10.1371/journal.pone.0045813 PMID:23029256

22. Miyaki K, Song Y, Suzuki T, Eguchi H, Kawakami N. DNA Methylation Status of the Methylenetetrahydrofolate Reductase Gene is associated with Depressive Symptoms in Japanese Workers: A Cross-Sectional Study. J Neurol Neurol Disord. 2015; 2:304. https://doi.org/10.15744/2454-4981.2.304

23. Emeny RT, Zierer A, Lacruz ME, Baumert J, Herder C, Gornitzka G, Koenig W, Thorand B, Ladwig KH, and KORA Investigators. Job strain-associated inflammatory burden and long-term risk of coronary events: findings from the MONICA/KORA Augsburg case-cohort study. Psychosom Med. 2013; 75:317-25.

https://doi.org/10.1097/PSY.0b013e3182860d63 PMID:23460721

24. Kivimäki M, Nyberg ST, Batty GD, Fransson El, Heikkilä $\mathrm{K}$, Alfredsson L, Bjorner JB, Borritz M, Burr H, Casini A, Clays E, De Bacquer D, Dragano N, et al, and IPD-Work Consortium. Job strain as a risk factor for coronary heart disease: a collaborative meta-analysis of individual participant data. Lancet. 2012; 380:1491-7. https://doi.org/10.1016/S0140-6736(12)60994-5 PMID:22981903

25. Nyberg ST, Fransson El, Heikkilä K, Ahola K, Alfredsson L, Bjorner JB, Borritz M, Burr H, Dragano N, Goldberg M, Hamer $M$, Jokela $M$, Knutsson $A$, et al, and IPDWork Consortium. Job strain as a risk factor for type 2 diabetes: a pooled analysis of 124,808 men and women. Diabetes Care. 2014; 37:2268-75. https://doi.org/10.2337/dc13-2936 PMID:25061139

26. Hintsanen $M$, Kivimäki $M$, Elovainio $M$, Pulkki-Råback $L$, Keskivaara $\mathrm{P}$, Juonala M, Raitakari OT, KeltikangasJärvinen L. Job strain and early atherosclerosis: the Cardiovascular Risk in Young Finns study. Psychosom Med. 2005; 67:740-7.

https://doi.org/10.1097/01.psy.0000181271.04169.93 PMID:16204432

27. Song $Y$, Miyaki $K$, Suzuki $T$, Sasaki $Y$, Tsutsumi $A$, Kawakami N, Shimazu A, Takahashi M, Inoue A, Kan C, Kurioka S, Shimbo T. Altered DNA methylation status of human brain derived neurotrophis factor gene could be useful as biomarker of depression. Am J Med Genet B Neuropsychiatr Genet. 2014; 165:357-64.

https://doi.org/10.1002/ajmg.b.32238 PMID:24801253

28. Cosmides L, Tooby J. Cognitive adaptations for social exchange. The adapted mind: Evolutionary psychology and the generation of culture. 1992; 163:163-228.

29. Dragano N, Siegrist J, Nyberg ST, Lunau T, Fransson El, Alfredsson L, Bjorner JB, Borritz $M$, Burr $H$, Erbel R, Fahlén G, Goldberg M, Hamer M, et al, and IPD-Work consortium. Effort-Reward Imbalance at Work and Incident Coronary Heart Disease: A Multicohort Study of 90,164 Individuals. Epidemiology. 2017; 28:619-26. https://doi.org/10.1097/EDE.0000000000000666 PMID:28570388

30. Siegrist J, Li J. Work Stress and Altered Biomarkers: A Synthesis of Findings Based on the Effort-Reward Imbalance Model. Int J Environ Res Public Health. 2017; 14:1373.

https://doi.org/10.3390/ijerph14111373 PMID:29125555

31. Levine $M E$, Lu AT, Quach A, Chen BH, Assimes $T L$, Bandinelli S, Hou L, Baccarelli AA, Stewart JD, Li Y, Whitsel EA, Wilson JG, Reiner AP, et al. An epigenetic biomarker of aging for lifespan and healthspan. Aging (Albany NY). 2018; 10:573-91. https://doi.org/10.18632/aging.101414 PMID:29676998

32. Lu AT, Quach A, Wilson JG, Reiner AP, Aviv A, Raj K, Hou L, Baccarelli AA, Li Y, Stewart JD, Whitsel EA, Assimes TL, Ferrucci L, Horvath S. DNA methylation GrimAge strongly predicts lifespan and healthspan. Aging (Albany NY). 2019; 11:303-27. https://doi.org/10.18632/aging.101684 PMID: $\underline{30669119}$

33. Belsky DW, Caspi A, Arseneault L, Baccarelli A, Corcoran DL, Gao X, Hannon E, Harrington HL, Rasmussen $L$, Houts R, Huffman K, Kraus WE, Kwon D, et al. Quantification of the pace of biological aging in humans through a blood test, the DunedinPoAm DNA methylation algorithm. Elife. 2020; 9:e54870. https://doi.org/10.7554/eLife.54870 PMID:32367804

34. Duchaine CS, Aubé K, Gilbert-Ouimet $M$, Vézina $M$, Ndjaboué R, Massamba $V$, Talbot $D$, Lavigne-Robichaud M, Trudel X, Pena-Gralle AB, Lesage A, Moore L, Milot $A$, et al. Psychosocial Stressors at Work and the Risk of Sickness Absence Due to a Diagnosed Mental Disorder: A Systematic Review and Meta-analysis. JAMA Psychiatry. 2020; 77:842-51. https://doi.org/10.1001/jamapsychiatry.2020.0322 PMID:32236498

35. Madsen IE, Nyberg ST, Magnusson Hanson LL, Ferrie JE, Ahola K, Alfredsson L, Batty GD, Bjorner JB, Borritz 
M, Burr H, Chastang JF, de Graaf R, Dragano N, et al, and IPD-Work Consortium. Job strain as a risk factor for clinical depression: systematic review and metaanalysis with additional individual participant data. Psychol Med. 2017; 47:1342-56.

https://doi.org/10.1017/S003329171600355X

PMID:28122650

36. Rugulies R, Aust B, Madsen IE. Effort-reward imbalance at work and risk of depressive disorders. A systematic review and meta-analysis of prospective cohort studies. Scand J Work Environ Health. 2017; 43:294-306.

https://doi.org/10.5271/sjweh.3632 PMID:28306759

37. Cillekens B, Huysmans MA, Holtermann A, van Mechelen W, Straker L, Krause N, van der Beek AJ, Coenen P. Physical activity at work may not be health enhancing. A systematic review with meta-analysis on the association between occupational physical activity and cardiovascular disease mortality covering 23 studies with 655892 participants. Scand J Work Environ Health. 2021; 3993.

https://doi.org/10.5271/sjweh.3993 PMID:34656067

38. Ek E, Ala-Mursula L, Velázquez RG, Tolvanen A, Salmela-Aro K. Employment trajectories until midlife associate with early social role investments and current work-related well-being. Advances in Life Course Research. 2021; 47:100391. https://doi.org/10.1016/i.alcr.2020.100391

39. Schaufeli WB, Bakker AB, Van Rhenen W. How changes in job demands and resources predict burnout, work engagement, and sickness absenteeism. Journal of Organizational Behavior: The International Journal of Industrial, Occupational and Organizational Psychology and Behavior. 2009; 30:893-917.

https://doi.org/10.1002/job.595

40. Virtanen M, Nyberg ST, Batty GD, Jokela M, Heikkilä K, Fransson El, Alfredsson L, Bjorner JB, Borritz M, Burr H, Casini A, Clays E, De Bacquer D, et al, and IPD-Work Consortium. Perceived job insecurity as a risk factor for incident coronary heart disease: systematic review and meta-analysis. BMJ. 2013; 347:f4746.

https://doi.org/10.1136/bmj.f4746

PMID:23929894

41. Rivera AS, Akanbi M, O’Dwyer LC, McHugh M. Shift work and long work hours and their association with chronic health conditions: A systematic review of systematic reviews with meta-analyses. PLoS One. 2020; 15:e0231037.

https://doi.org/10.1371/journal.pone.0231037 PMID:32240254

42. Virtanen M, Kivimäki M. Long Working Hours and Risk of Cardiovascular Disease. Curr Cardiol Rep. 2018; 20:123. https://doi.org/10.1007/s11886-018-1049-9 PMID:30276493

43. Virtanen M, Ferrie JE, Gimeno D, Vahtera J, Elovainio $M$, Singh-Manoux A, Marmot MG, Kivimäki M. Long working hours and sleep disturbances: the Whitehall II prospective cohort study. Sleep. 2009; 32:737-45.

https://doi.org/10.1093/sleep/32.6.737 PMID:19544749

44. Nakashima M, Morikawa $Y$, Sakurai M, Nakamura K, Miura K, Ishizaki M, Kido T, Naruse $Y$, Suwazono $Y$, Nakagawa $\mathrm{H}$. Association between long working hours and sleep problems in white-collar workers. J Sleep Res. 2011; 20:110-6.

https://doi.org/10.1111/i.1365-2869.2010.00852.x PMID:20561174

45. Virtanen $M$, Magnusson Hansson L, Goldberg $M$, Zins M, Stenholm S, Vahtera J, Westerlund $H$, Kivimäki M. Long working hours, anthropometry, lung function, blood pressure and blood-based biomarkers: cross-sectional findings from the CONSTANCES study. J Epidemiol Community Health. 2019; 73:130-5.

https://doi.org/10.1136/jech-2018-210943

PMID:30327450

46. Weston G, Zilanawala A, Webb E, Carvalho LA, McMunn A. Long work hours, weekend working and depressive symptoms in men and women: findings from a UK population-based study. J Epidemiol Community Health. 2019; 73:465-74.

https://doi.org/10.1136/jech-2018-211309 PMID:

47. Beydoun MA, Hossain S, Chitrala KN, Tajuddin SM, Beydoun HA, Evans MK, Zonderman AB. Association between epigenetic age acceleration and depressive symptoms in a prospective cohort study of urbandwelling adults. J Affect Disord. 2019; 257:64-73.

https://doi.org/10.1016/i.jad.2019.06.032 PMID:31299406

48. Han LK, Aghajani M, Clark SL, Chan RF, Hattab MW, Shabalin AA, Zhao M, Kumar G, Xie LY, Jansen R, Milaneschi Y, Dean B, Aberg KA, et al. Epigenetic Aging in Major Depressive Disorder. Am J Psychiatry. 2018; 175:774-82.

https://doi.org/10.1176/appi.ajp.2018.17060595 PMID:29656664

49. Rivera-Torres $\mathrm{P}$, Araque-Padilla RA, Montero-Simó MJ. Job stress across gender: the importance of emotional and intellectual demands and social support in women. Int J Environ Res Public Health. 2013; 10:375-89.

https://doi.org/10.3390/ijerph10010375 PMID:23343989

50. Gadinger MC, Fischer JE, Schneider S, Terris DD, Krückeberg K, Yamamoto S, Frank G, Kromm W. 
Gender moderates the health-effects of job strain in managers. Int Arch Occup Environ Health. 2010; 83:531-41.

https://doi.org/10.1007/s00420-009-0477-7

PMID:19888594

51. Wege N, Li J, Siegrist J. Are there gender differences in associations of effort-reward imbalance at work with self-reported doctor-diagnosed depression? Prospective evidence from the German SocioEconomic Panel. Int Arch Occup Environ Health. 2018; 91:435-43.

https://doi.org/10.1007/s00420-018-1293-8 PMID:29380045

52. Gibson J, Russ TC, Clarke TK, Howard DM, Hillary RF, Evans KL, Walker RM, Bermingham ML, Morris SW, Campbell A, Hayward C, Murray AD, Porteous DJ, et al. A meta-analysis of genome-wide association studies of epigenetic age acceleration. PLoS Genet. 2019; 15:e1008104.

https://doi.org/10.1371/journal.pgen.1008104 PMID: 31738745

53. Lau CE, Robinson O. DNA methylation age as a biomarker for cancer. Int J Cancer. 2021; 148:2652-63. https://doi.org/10.1002/ijc.33451 PMID:33394520

54. Kresovich JK, Martinez Lopez AM, Garval EL, Xu Z, White AJ, Sandler DP, Taylor JA. Alcohol Consumption and Methylation-Based Measures of Biological Age. J Gerontol A Biol Sci Med Sci. 2021; 76:2107-11. https://doi.org/10.1093/gerona/glab149 PMID:34038541

55. Singmann $P$, Shem-Tov D, Wahl S, Grallert $H$, Fiorito $G$, Shin SY, Schramm K, Wolf $P$, Kunze $S$, Baran $Y$, Guarrera $S$, Vineis $P$, Krogh V, et al. Characterization of wholegenome autosomal differences of DNA methylation between men and women. Epigenetics Chromatin. 2015; 8:43.

https://doi.org/10.1186/s13072-015-0035-3 PMID:26500701

56. Quach A, Levine ME, Tanaka T, Lu AT, Chen BH, Ferrucci L, Ritz B, Bandinelli S, Neuhouser ML, Beasley JM, Snetselaar L, Wallace RB, Tsao PS, et al. Epigenetic clock analysis of diet, exercise, education, and lifestyle factors. Aging (Albany NY). 2017; 9:419-46.

https://doi.org/10.18632/aging.101168

PMID:28198702

57. McCrory C, Fiorito G, Hernandez B, Polidoro S, O'Halloran AM, Hever A, Ni Cheallaigh C, Lu AT, Horvath S, Vineis P, Kenny RA. GrimAge Outperforms Other Epigenetic Clocks in the Prediction of AgeRelated Clinical Phenotypes and All-Cause Mortality. J Gerontol A Biol Sci Med Sci. 2021; 76:741-9.

https://doi.org/10.1093/gerona/glaa286

PMID:33211845
58. Karasek R, Brisson C, Kawakami N, Houtman I, Bongers $\mathrm{P}$, Amick B. The Job Content Questionnaire (JCQ): an instrument for internationally comparative assessments of psychosocial job characteristics. J Occup Health Psychol. 1998; 3:322-55.

https://doi.org/10.1037//1076-8998.3.4.322 PMID: $\underline{9805280}$

59. Freni-Sterrantino A, Salerno V. A Plea for the Need to Investigate the Health Effects of Gig-Economy. Front Public Health. 2021; 9:638767. https://doi.org/10.3389/fpubh.2021.638767 PMID:33634072

60. Rantakallio P. Groups at risk in low birth weight infants and perinatal mortality. Acta Paediatr Scand. 1969; 193. PMID:4911003

61. Rantakallio P. The longitudinal study of the northern Finland birth cohort of 1966. Paediatr Perinat Epidemiol. 1988; 2:59-88. https://doi.org/10.1111/i.1365-3016.1988.tb00180.x PMID:2976931

62. Wiklund $P$, Karhunen $V$, Richmond RC, Parmar $P$, Rodriguez A, De Silva M, Wielscher M, Rezwan Fl, Richardson TG, Veijola J, Herzig KH, Holloway JW, Relton $\mathrm{CL}$, et al. DNA methylation links prenatal smoking exposure to later life health outcomes in offspring. Clin Epigenetics. 2019; 11:97. https://doi.org/10.1186/s13148-019-0683-4 PMID:31262328

63. Levine ME. Modeling the rate of senescence: can estimated biological age predict mortality more accurately than chronological age? J Gerontol A Biol Sci Med Sci. 2013; 68:667-74. https://doi.org/10.1093/gerona/gls233 PMID:23213031

64. Siegrist J. Adverse health effects of high-effort/lowreward conditions. J Occup Health Psychol. 1996; 1:27-41. https://doi.org/10.1037//1076-8998.1.1.27 PMID: 9547031

65. Kahn H, Wiener AJ. year 2000; a framework for speculation on the next thirty-three years 1967. FAO of UN. https://agris.fao.org/agrissearch/search.do?recordID=US201300314687

66. Schaufeli W, Salanova M, González-Romà, Bakker A. The measurement of Engagement and Burnout: A two sample confirmatory factor anañytic approach. 2008; 3:71-92.

https://doi.org/10.1023/A:1015630930326

67. Rautio N, Varanka-Ruuska T, Vaaramo E, Palaniswamy S, Nedelec R, Miettunen J, Karppinen J, Auvinen J, Järvelin MR, Keinänen-Kiukaanniemi S, 
Sebert S, Ala-Mursula L. Accumulated exposure to unemployment is related to impaired glucose metabolism in middle-aged men: A follow-up of the Northern Finland Birth Cohort 1966. Prim Care Diabetes. 2017; 11:365-72.

https://doi.org/10.1016/i.pcd.2017.03.010

PMID:28456438
68. Tammelin T, Näyhä S, Hills AP, Järvelin MR. Adolescent participation in sports and adult physical activity. Am J Prev Med. 2003; 24:22-8.

https://doi.org/10.1016/s0749-3797(02)00575-5

PMID: $\underline{12554020}$ 


\section{SUPPLEMENTARY MATERIALS}

\section{Work-related stress and well-being in association with epigenetic age acceleration: A Northern Finland Birth Cohort 1966 Study}

\section{DNA data collection}

Fasting blood samples were collected at follow-up of participants at ages 31 and 46 years and stored at $-80^{\circ} \mathrm{C}$ for subsequent biomarker profiling DNA samples were obtained from 5,923 subjects from NFBC1966. In 2012, all individuals with a known address in Finland were sent postal questionnaires and an invitation for a clinical examination questionnaire and clinical data was collected for 5539 participants. DNA methylation at 46 years was extracted for 807 randomly selected subjects with both questionnaire and clinical data. Among these individuals, DNA methylation data at 46 years were for 766 subjects. Detailed and technical aspects are reported [1].

\section{Work-related indicators' definitions}

\section{Job strain}

We computed the job strain dimension using a modified Karasek's Job Content Questionnaire [2]. Job control was measured using 9 items (Cronbach $\alpha=0.86$ ) and questions were rated from 'very little' (1) to 'a lot' (5). Job Control contains 3 items on the ability to use skills and learning new things and 6 items on the possibilities to decision making: influencing work tasks, order of performing tasks, work pace, methods, distribution, and with whom to work.

Job demands were measured using 4 items (Cronbach $\alpha$ $=0$. 81), investigating to what extent the following capabilities are required in performing own work: Reacting quickly, Paying attention to details, Patience, and Concentration. They were rated from' almost not at all' (1) to 'very much' (5). We first averaged the scores for control and demands items and analysed them separately, and then constructed 4 alternative formulations of job strain that have previously been used in studies on the demand-control model [3]:

i. The linear term was a continuous job strain variable obtained from the following equation: $(0.5 \mathrm{x}$ job demand score $)$ - ( $0.5 \mathrm{x}$ job control score $)$.

ii. The categories were classified as "high strain" (high demands and low job control), "active" (high demands and high control), "passive" (low demands and low control), and "low strain" (low demands and high control), dividing demand and control at their median score [4]. iii. The quotient term was formed by dividing the sum of job demands by the sum of job control.

iv. The tertile job strain divided the distributions of demands and job control into thirds, as in a previous study by Green and Johnson [5]. The highest 2 tertiles in demands combined with the lowest 2 tertiles in job control formed the high-strain category. The lowest 2 tertiles in demands combined with the highest 2 tertiles in control formed the lowstrain category. All other combinations were placed into the intermediate strain category. Job strain was coded as an ordinal variable ranging from low, intermediate, and high strain.

\section{Effort-reward imbalance (ERI)}

We measured the Effort-Reward imbalance (ERI) using the Occupational Stress Questionnaire [6]. Effort was measured with a three-item scale (e.g., 'I have constant time pressure due to a heavy workload') (Cronbach's $\alpha=$ $0.69)$ and reward with a four-item scale for reward (e.g., 'I receive the respect I deserve from my superiors') $(\alpha=$ 0.05 ), all rated on a scale from 1 (strongly agree) to 4 (strongly disagree). The Effort scale measures employees' time and energy invested in the job. The Reward scale, in turn, assesses contentment with the amount of salary, job security and self-acceptance at work. ERI was calculated by dividing the mean score of effort by the mean score of reward. That is, struggling with high efforts but receiving low rewards is postulated to increase the risk for experiencing work stress [7]. Hence, high scores of the ratio (effort/ reward) refer to higher job stress.

\section{Overcommitment}

We assessed overcommitment [6] using the sum of 6 items (Cronbach $\alpha=0.43$ ) rated from 'totally agree' (1) to 'totally disagree' (4). Questions investigated agreement with the statements of feeling easily paralyzed by the time pressures of the work; starting to think about work as soon as waking up in the morning; finding it easy to relax and "switch off" when coming home from work; the close ones telling me that I sacrifice too much to my work; being rarely able to let go of work stuff which stays on my mind when I go to bed; and having it difficult to fall asleep when postponing something that was due today.

\section{Occupational physical activity (OPA)}

Levels of physical job strenuousness were evaluated using the question "to what extent are the following tasks and postures part of your job." The participants had to evaluate the extent of certain tasks (e.g., "heavy 
physical work in which the body has to struggle," "lifting loads over $15 \mathrm{~kg}$ ") and postures (e.g., "standing," "bending") in their work. The response scale was from 'not at all or very rarely' (1) to 'very often' (5). We summed and divided the scores into three groups on the basis of the tertile cut-offs: low, moderate, and high intensity [8].

\section{Employment history}

From the questionnaire, we selected the question [9]: which of the following alternatives (from always continuously employed to never in gainful employment) best describes your employment history? We created two groups: the' Continuously employed' including those who answered, 'I have always been employed through my work history' and the 'at least temporary unemployed' including those who answered to have experienced occasional unemployment, more time as unemployed than as employed or never have done paid work.

\section{Working hours and shift}

From the questionnaire, we selected the question 'how many hours of paid work do you do on average per week?' and we categorized in three levels: less than 31 hours per week, 31-40 hours, and more than 40 hours. And to assess when those working hours occurred, we split the answers between 'day job (06-18)' and 'evening/shift job'.

\section{Work-favouring attitude}

Reflecting personal attitude and commitment towards one's work-related social role, work favouring attitude was measured using the scale introduced by Kahn and Wiener [10]. Of the original six items, five represent positive work-favouring attitudes (e.g., "Work, for me, is a calling, or a way to exercise and master gratifying skills, or a means to provide income") and one item represents a negative attitude ("Work is a necessary evil one has to do to make a living"), that was excluded (Cronbach $\alpha=0$. 79). In remaining 5-item scale was used indicating the magnitude of a positive work-favouring attitude, answers ranging from 'very little' (1) to 'very much' (5) [11].

\section{Work engagement}

Work engagement is obtained as the sum of the score of 9 items (Cronbach $\alpha=0.92$ ) using the Utrecht Work Engagement Scale [12]. We used the mean score [11] of nine items measured on a 7-point Likert-scale (e.g., "I feel bursting with energy when I am working") asking how often the item could be endorsed by the participant (ranging from $0=$ never to $6=$ everyday).

\section{Job security}

We assessed with one question the perception of job security and collapsed the four possible answers from 'very good' (1) to 'very poor' (4), in two levels 'Yes' (1 and 2) and 'No' (3 and 4).

\section{REFERENCES}

1. Sovio U, Bennett AJ, Millwood IY, Molitor J, O'Reilly PF, Timpson NJ, Kaakinen M, Laitinen J, Haukka J, Pillas D, Tzoulaki I, Molitor J, Hoggart C, et al. Genetic determinants of height growth assessed longitudinally from infancy to adulthood in the northern Finland birth cohort 1966. PLoS Genet. 2009; 5:e1000409. https://doi.org/10.1371/journal.pgen.1000409 PMID: 19266077

2. Karasek R, Brisson C, Kawakami N, Houtman I, Bongers $P$, Amick B. The Job Content Questionnaire (JCQ): an instrument for internationally comparative assessments of psychosocial job characteristics. J Occup Health Psychol. 1998; 3:322-55.

https://doi.org/10.1037//1076-8998.3.4.322 PMID:9805280

3. Hintsanen $M$, Kivimäki $M$, Elovainio $M$, Pulkki-Råback $L$, Keskivaara P, Juonala M, Raitakari OT, KeltikangasJärvinen L. Job strain and early atherosclerosis: the Cardiovascular Risk in Young Finns study. Psychosom Med. 2005; 67:740-7. https://doi.org/10.1097/01.psy.0000181271.04169.93 PMID: 16204432

4. Kujala V, Tammelin T, Remes J, Vammavaara E, Ek E, Laitinen J. Work ability index of young employees and their sickness absence during the following year. Scand J Work Environ Health. 2006; 32:75-84. https://doi.org/10.5271/sjweh.979 PMID:16539175

5. Green KL, Johnson JV. The effects of psychosocial work organization on patterns of cigarette smoking among male chemical plant employees. Am J Public Health. 1990; 80:1368-71.

https://doi.org/10.2105/ajph.80.11.1368 PMID:2240307

6. Siegrist J, Starke D, Chandola T, Godin I, Marmot M, Niedhammer I, Peter R. The measurement of effortreward imbalance at work: European comparisons. Soc Sci Med. 2004; 58:1483-99. https://doi.org/10.1016/S0277-9536(03)00351-4 PMID:14759692

7. Siegrist J. Adverse health effects of high-effort/lowreward conditions. J Occup Health Psychol. 1996; 1:27-41. https://doi.org/10.1037//1076-8998.1.1.27 PMID: 9547031 
8. Nevanperä N, Seitsamo J, Ala-Mursula L, Remes J, Hopsu L, Auvinen J, Tammelin T, Järvelin MR, Laitinen J. Perceived Work Ability in the Light of Long-Term and Stress-Related Unhealthy Behaviorsa Prospective Cohort Study. Int J Behav Med. 2016; 23:179-89.

https://doi.org/10.1007/s12529-015-9512-0

PMID:26500090

9. Punakallio A, Lusa S, Ala-Mursula L, Ek E, Nevanperä N, Remes J, Auvinen J, Seitsamo J, Karppinen J, Laitinen J. Personal meaning of work and perceived work ability among middle-aged workers with physically strenuous work: a Northern Finland Birth Cohort 1966 Study. Int Arch Occup Environ Health. 2019; 92:371-81. https://doi.org/10.1007/s00420-019-01412-9 PMID:30767053
10. Kahn H, Wiener AJ. year 2000; a framework for speculation on the next thirty-three years. 1967. FAO of UN https://agris.fao.org/agrissearch/search.do?recordID=US201300314687

11. Ek E, Ala-Mursula L, Velázquez RG, Tolvanen A, Salmela-Aro K. Employment trajectories until midlife associate with early social role investments and current work-related well-being. Advances in Life Course Research. 2021; 47:100391. https://doi.org/10.1016/i.alcr.2020.100391

12. Schaufeli W, Salanova M, González-Romà, Bakker, A. The measurement of Engagement and Burnout: A two sample confirmatory factor anañytic approach. 2008:71-92.

https://doi.org/10.1023/A:1015630930326 


\section{Supplementary Figure}

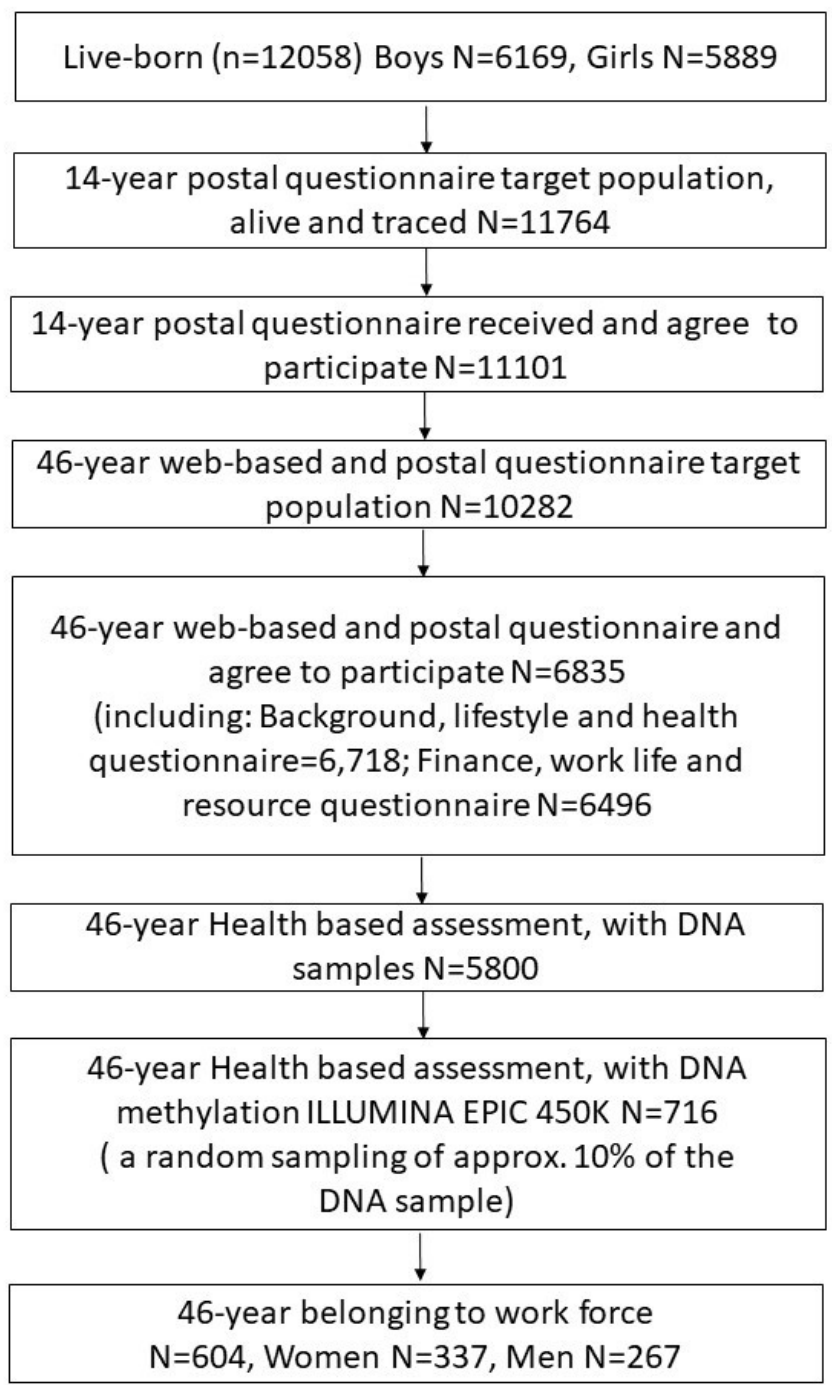

Supplementary Figure 1. Flowchart of the study population in the NFBC 1966. 


\section{Supplementary Tables}

Supplementary Table 1. P-values for analysis of variance (ANOVA) and chi-square test, for all job exposures and risk factors.

\begin{tabular}{lcccccc}
\hline $\begin{array}{l}\text { ANOVA } \\
\text { P-values }\end{array}$ & Sex* & BMI & Education & Physical activity & Alcohol consumption & Smoking \\
\hline Control & 0.04 & 0.18 & $<0.001$ & 0.34 & 0.82 & 0.65 \\
Demand & $<0.001$ & 0.31 & $<0.001$ & 0.24 & 0.12 & 0.38 \\
Job strain & $<0.001$ & 0.45 & $<0.001$ & 0.57 & 0.32 & 0.45 \\
Job strain linear & $<0.001$ & 0.33 & $<0.001$ & 0.37 & 0.23 & 0.5 \\
Job strain quotient & $<0.001$ & 0.45 & $<0.001$ & 0.57 & 0.32 & 0.45 \\
Effort & 0.01 & 0.62 & $<0.001$ & 0.47 & 0.61 & $<0.001$ \\
Reward & 0.29 & 0.56 & 0.03 & 0.91 & $<0.001$ & 0.22 \\
Effort-Reward Imbalance & 0.03 & 0.9 & 0.2 & 0.58 & 0.24 & 0.02 \\
Overcommitment & 0.02 & 0.35 & 0.05 & 0.08 & 0.91 & 0.09 \\
Work attitude & $<0.001$ & 0.54 & $<0.001$ & 0.1 & 0.2 & 0.24 \\
Work engagement & $<0.001$ & 0.49 & $<0.001$ & 0.06 & 0.05 & 0.1 \\
Chi Square & & & & & & 0.7 \\
P-values & & & & & 0.03 & $<.001$ \\
Job status & $<0.001$ & 0.61 & 0.27 & 0.86 & 0.3 & $<0.001$ \\
Employer & $<0.001$ & 0.17 & $<0.001$ & 0.57 & 0.28 & 0.75 \\
Occupational group & 0.98 & 0.81 & $<0.001$ & 0.86 & 0.07 & 0.71 \\
Job Strain quartile & $<0.001$ & 0.3 & $<0.001$ & 0.89 & 0.76 & 0.2 \\
Job Strain Revised & $<0.001$ & 0.05 & $<0.001$ & 0.16 & 0.55 & 0.06 \\
Work history & 0.26 & 0.38 & 0.05 & 0.86 & 0.05 & 0.36 \\
OPA & 0.21 & 0.05 & $<0.001$ & 0.71 & 0.19 & 0.13 \\
Working hours & $<0.001$ & 0.87 & 0.04 & 0.12 & 0.66 & \\
Shift & 0.53 & 0.14 & $<0.001$ & 0.95 & & \\
Job Security & 0.84 & 0.7 & 0.91 & & & \\
\hline
\end{tabular}

*For sex is a t-test as it has only two levels.

Supplementary Table 2. Pearson correlations among extrinsic epigenetic age acceleration and pace of ageing.

\begin{tabular}{lcccc}
\hline N=604 & Horvath & Hannum & PhenoAge & GrimAge \\
\hline Horvath & & & & \\
Hannum & 0.96 & & & \\
PhenoAge & 0.48 & 0.47 & & \\
GrimAge & 0.23 & 0.20 & 0.31 & 0.78 \\
DunedinPoAm & 0.24 & 020 & 0.33 & \\
\hline
\end{tabular}


Supplementary Table 3. Adjusted coefficient estimates from linear regression with $95 \%$ confidence intervals.

\begin{tabular}{|c|c|c|c|c|c|c|}
\hline & & HorvathAA & HannumAA & PhenoAgeAA & GrimAgeAA & DunedinPoAm \\
\hline & & $\begin{array}{l}\text { Estimates } \\
(95 \% \text { CI })\end{array}$ & $\begin{array}{l}\text { Estimates } \\
(95 \% \text { CI })\end{array}$ & $\begin{array}{l}\text { Estimates } \\
(95 \% \text { CI })\end{array}$ & $\begin{array}{l}\text { Estimates } \\
(95 \% \text { CI })\end{array}$ & $\begin{array}{l}\text { Estimates } \\
(95 \% \text { CI })\end{array}$ \\
\hline \multirow{3}{*}{ Job Status } & permanent & Ref. & Ref. & Ref. & Ref. & Ref. \\
\hline & temporary & $\begin{array}{c}-1.127 \\
(-2.422,0.168)\end{array}$ & $\begin{array}{c}-0.694 \\
(-1.661,0.272)\end{array}$ & $\begin{array}{c}-0.505 \\
(-2.017,1.008)\end{array}$ & $\begin{array}{c}0.631 \\
(-0.341,1.602)\end{array}$ & $\begin{array}{c}0.005 \\
(-0.013,0.023)\end{array}$ \\
\hline & unemployed & $\begin{array}{c}0.063 \\
(-1.325,1.451)\end{array}$ & $\begin{array}{c}-0.006 \\
(-1.042,1.03)\end{array}$ & $\begin{array}{c}0.817 \\
(-0.804,2.438)\end{array}$ & $\begin{array}{c}0.602 \\
(-0.439,1.644)\end{array}$ & $\begin{array}{c}0.004 \\
(-0.015,0.023)\end{array}$ \\
\hline & private employer & Ref. & Ref. & Ref. & Ref. & Ref. \\
\hline Employer & state/municipality & $\begin{array}{c}0.063 \\
(-0.699,0.825)\end{array}$ & $\begin{array}{c}0.048 \\
(-0.522,0.618)\end{array}$ & $\begin{array}{c}0.116 \\
(-0.775,1.008)\end{array}$ & $\begin{array}{c}-0.096 \\
(-0.655,0.463)\end{array}$ & $\begin{array}{c}0 \\
(-0.011,0.01)\end{array}$ \\
\hline \multirow[b]{2}{*}{$\begin{array}{l}\text { Occupational } \\
\text { group }\end{array}$} & Blue collars & Ref. & Ref. & Ref. & Ref. & Ref. \\
\hline & White collars & $\begin{array}{c}0.509 \\
(-0.274,1.292)\end{array}$ & $\begin{array}{c}0.318 \\
(-0.268,0.905)\end{array}$ & $\begin{array}{c}0.257 \\
(-0.653,1.166)\end{array}$ & $\begin{array}{c}-0.683 \\
(-1.264,-0.102) \\
*\end{array}$ & $\begin{array}{c}-0.002 \\
(-0.013,0.008)\end{array}$ \\
\hline Job control & & $\begin{array}{c}0.317 \\
(-0.149,0.782)\end{array}$ & $\begin{array}{c}0.169 \\
(-0.179,0.517)\end{array}$ & $\begin{array}{c}-0.186 \\
(-0.73,0.359)\end{array}$ & $\begin{array}{c}-0.154 \\
(-0.508,0.199)\end{array}$ & $\begin{array}{c}-0.001 \\
(-0.007,0.006)\end{array}$ \\
\hline Job demand & & $\begin{array}{c}0.086 \\
(-0.446,0.618)\end{array}$ & $\begin{array}{c}0.118 \\
(-0.279,0.514)\end{array}$ & $\begin{array}{c}-0.483 \\
(-1.103,0.137)\end{array}$ & $\begin{array}{c}-0.018 \\
(-0.42,0.384)\end{array}$ & $\begin{array}{c}-0.004 \\
(-0.012,0.003)\end{array}$ \\
\hline Job strain Linear & & $\begin{array}{c}-0.41 \\
(-1.234,0.415)\end{array}$ & $\begin{array}{c}-0.154 \\
(-0.769,0.462)\end{array}$ & $\begin{array}{c}-0.354 \\
(-1.314,0.605)\end{array}$ & $\begin{array}{c}0.157 \\
(-0.465,0.779)\end{array}$ & $\begin{array}{c}-0.005 \\
(-0.017,0.006)\end{array}$ \\
\hline \multirow{4}{*}{ Job strain } & Low strain & Ref. & Ref. & Ref. & Ref. & Ref. \\
\hline & active work & $\begin{array}{c}0.217 \\
(-0.724,1.158)\end{array}$ & $\begin{array}{c}0.271 \\
(-0.431,0.973)\end{array}$ & $\begin{array}{c}-1.301 \\
(-2.391,-0.212) *\end{array}$ & $\begin{array}{c}0.254 \\
(-0.454,0.963)\end{array}$ & $\begin{array}{c}-0.005 \\
(-0.018,0.009)\end{array}$ \\
\hline & passive work & $\begin{array}{c}0.177 \\
(-0.856,1.21)\end{array}$ & $\begin{array}{c}0.223 \\
(-0.547,0.994)\end{array}$ & $\begin{array}{c}-0.666 \\
(-1.862,0.53)\end{array}$ & $\begin{array}{c}0.518 \\
(-0.26,1.296)\end{array}$ & $\begin{array}{c}0.005 \\
(-0.01,0.019)\end{array}$ \\
\hline & high strain & $\begin{array}{c}-0.189 \\
(-1.256,0.877)\end{array}$ & $\begin{array}{c}-0.037 \\
(-0.832,0.759)\end{array}$ & $\begin{array}{c}-0.527 \\
(-1.761,0.708)\end{array}$ & $\begin{array}{c}0.526 \\
(-0.277,1.329)\end{array}$ & $\begin{array}{c}0(- \\
0.015,0.015)\end{array}$ \\
\hline $\begin{array}{l}\text { Job strain } \\
\text { quotient }\end{array}$ & & $\begin{array}{c}-0.843 \\
(-2.066,0.379)\end{array}$ & $\begin{array}{c}-0.414 \\
(-1.328,0.499)\end{array}$ & $\begin{array}{c}-0.568 \\
(-1.992,0.855)\end{array}$ & $\begin{array}{c}0.234 \\
(-0.69,1.157)\end{array}$ & $\begin{array}{c}-0.009 \\
(-0.026,0.008)\end{array}$ \\
\hline \multirow{3}{*}{ Job strain tertile } & Low strain & Ref. & Ref. & Ref. & Ref. & Ref. \\
\hline & $\begin{array}{l}\text { Intermediate } \\
\text { strain }\end{array}$ & $\begin{array}{c}-0.328 \\
(-1.194,0.538)\end{array}$ & $\begin{array}{c}-0.101 \\
(-0.748,0.545)\end{array}$ & $\begin{array}{c}-0.942 \\
(-1.946,0.062)\end{array}$ & $\begin{array}{c}0.31 \\
(-0.343,0.963)\end{array}$ & $\begin{array}{c}0.001 \\
(-0.012,0.013)\end{array}$ \\
\hline & high strain & $\begin{array}{c}-0.226 \\
(-1.109,0.657)\end{array}$ & $\begin{array}{c}-0.032 \\
(-0.691,0.627)\end{array}$ & $\begin{array}{c}-0.283 \\
(-1.307,0.741)\end{array}$ & $\begin{array}{c}0.133 \\
(-0.532,0.799)\end{array}$ & $\begin{array}{c}-0.002 \\
(-0.014,0.011)\end{array}$ \\
\hline Effort & & $\begin{array}{c}-0.582 \\
(-1.098,-0.066) *\end{array}$ & $\begin{array}{c}-0.44 \\
(-0.825,-0.054) *\end{array}$ & $\begin{array}{c}-0.323 \\
(-0.932,0.285)\end{array}$ & $\begin{array}{c}0.013 \\
(-0.381,0.408)\end{array}$ & $\begin{array}{c}0.001 \\
(-0.006,0.008)\end{array}$ \\
\hline Reward & & $\begin{array}{c}0.115 \\
(-0.53,0.76)\end{array}$ & $\begin{array}{c}0.212 \\
(-0.27,0.693)\end{array}$ & $\begin{array}{c}0.049 \\
(-0.705,0.803)\end{array}$ & $\begin{array}{c}0.095 \\
(-0.391,0.58)\end{array}$ & $\begin{array}{c}-0.005 \\
(-0.014,0.004)\end{array}$ \\
\hline $\begin{array}{l}\text { Effort-Reward } \\
\text { Imbalance }\end{array}$ & & $\begin{array}{c}-0.734 \\
(-1.598,0.13)\end{array}$ & $\begin{array}{c}-0.61 \\
(-1.255,0.036)\end{array}$ & $\begin{array}{c}-0.38 \\
(-1.394,0.634)\end{array}$ & $\begin{array}{c}0.021 \\
(-0.632,0.673)\end{array}$ & $\begin{array}{c}0.004 \\
(-0.008,0.016)\end{array}$ \\
\hline Overcommitment & & $\begin{array}{c}0.097 \\
(-0.448,0.641)\end{array}$ & $\begin{array}{c}0.065 \\
(-0.343,0.472)\end{array}$ & $\begin{array}{c}0.24 \\
(-0.396,0.876)\end{array}$ & $\begin{array}{c}-0.029 \\
(-0.443,0.386)\end{array}$ & $\begin{array}{c}0 \\
(-0.008,0.008)\end{array}$ \\
\hline \multirow[t]{2}{*}{ Work history } & $\begin{array}{c}\text { At least } \\
\text { temporary } \\
\text { unemployed }\end{array}$ & Ref. & Ref. & Ref. & Ref. & Ref. \\
\hline & $\begin{array}{l}\text { Continuously } \\
\text { Employed }\end{array}$ & $\begin{array}{c}0.205 \\
(-0.46,0.87)\end{array}$ & $\begin{array}{c}0.232 \\
(-0.263,0.728)\end{array}$ & $\begin{array}{c}-0.064 \\
(-0.838,0.709)\end{array}$ & $\begin{array}{c}-0.406 \\
(-0.905,0.092)\end{array}$ & $\begin{array}{c}-0.005 \\
(-0.014,0.005)\end{array}$ \\
\hline $\begin{array}{l}\text { Occupational } \\
\text { Physical Activity }\end{array}$ & Low Intensity & Ref. & Ref. & Ref. & Ref. & Ref. \\
\hline \multirow{2}{*}{ strenuousness } & $\begin{array}{l}\text { Intermediate } \\
\text { Intensity }\end{array}$ & $\begin{array}{c}-0.357 \\
(-1.42,0.705)\end{array}$ & $\begin{array}{c}-0.176 \\
(-0.971,0.618)\end{array}$ & $\begin{array}{c}0.472 \\
(-0.775,1.719)\end{array}$ & $\begin{array}{c}0.638 \\
(-0.169,1.445)\end{array}$ & $\begin{array}{c}0.002 \\
(-0.013,0.017)\end{array}$ \\
\hline & High Intensity & $\begin{array}{c}-0.345 \\
(-1.406,0.715)\end{array}$ & $\begin{array}{c}-0.087 \\
(-0.88,0.705)\end{array}$ & $\begin{array}{c}0.623 \\
(-0.621,1.867)\end{array}$ & $\begin{array}{c}0.017 \\
(-0.787,0.822)\end{array}$ & $\begin{array}{c}-0.013 \\
(-0.028,0.002)\end{array}$ \\
\hline $\begin{array}{l}\text { Working hours } \\
\text { per week }\end{array}$ & $\begin{array}{c}\text { less than } 31 \\
\text { hours }\end{array}$ & Ref. & Ref. & Ref. & Ref. & Ref. \\
\hline
\end{tabular}




\begin{tabular}{|c|c|c|c|c|c|c|}
\hline & $31-40$ hours & $\begin{array}{c}1.511 \\
(-0.001,3.022) *\end{array}$ & $\begin{array}{c}1.171 \\
(0.042,2.3) *\end{array}$ & $\begin{array}{c}-0.446 \\
(-2.227,1.336)\end{array}$ & $\begin{array}{c}-0.629 \\
(-1.783,0.526)\end{array}$ & $\begin{array}{c}-0.006 \\
(-0.028,0.015)\end{array}$ \\
\hline & $\begin{array}{c}\text { more than } 40 \\
\text { hours }\end{array}$ & $\begin{array}{c}2.009 \\
(0.368,3.651) *\end{array}$ & $\begin{array}{c}1.547 \\
(0.321,2.772) *\end{array}$ & $\begin{array}{c}0.197 \\
(-1.737,2.132)\end{array}$ & $\begin{array}{c}-0.657 \\
(-1.911,0.597)\end{array}$ & $\begin{array}{c}-0.005 \\
(-0.028,0.018)\end{array}$ \\
\hline \multirow[b]{2}{*}{ Working shift } & Day job & Ref. & Ref. & Ref. & Ref. & Ref. \\
\hline & Evening/shift & $\begin{array}{c}0.346 \\
(-0.54,1.232)\end{array}$ & $\begin{array}{c}0.342 \\
(-0.322,1.005)\end{array}$ & $\begin{array}{c}0.481 \\
(-0.562,1.524)\end{array}$ & $\begin{array}{c}0.176 \\
(-0.5,0.852)\end{array}$ & $\begin{array}{c}0.007 \\
(-0.005,0.02)\end{array}$ \\
\hline Work attitude & & $\begin{array}{c}0.025 \\
(-0.073,0.123)\end{array}$ & $\begin{array}{c}0.01 \\
(-0.063,0.083)\end{array}$ & $\begin{array}{c}-0.006 \\
(-0.12,0.109)\end{array}$ & $\begin{array}{c}0.04 \\
(-0.033,0.112)\end{array}$ & $\begin{array}{c}0 \\
(-0.002,0.001)\end{array}$ \\
\hline $\begin{array}{l}\text { Work } \\
\text { engagement }\end{array}$ & & $\begin{array}{c}0.012 \\
(-0.022,0.046)\end{array}$ & $\begin{array}{c}0.008 \\
(-0.018,0.034)\end{array}$ & $\begin{array}{c}0.01 \\
(-0.03,0.05)\end{array}$ & $\begin{array}{c}-0.01 \\
(-0.036,0.016)\end{array}$ & $\begin{array}{c}0 \\
(-0.001,0)\end{array}$ \\
\hline \multirow[b]{2}{*}{ Job security } & No & Ref. & Ref. & Ref. & Ref. & Ref. \\
\hline & Yes & $\begin{array}{c}1.115 \\
(0.16,2.071) *\end{array}$ & $\begin{array}{c}0.841 \\
(0.127,1.555) *\end{array}$ & $\begin{array}{c}1.015 \\
(-0.109,2.138)\end{array}$ & $\begin{array}{c}-0.01 \\
(-0.74,0.72)\end{array}$ & $\begin{array}{c}-0.004 \\
(-0.018,0.009)\end{array}$ \\
\hline
\end{tabular}

Fully adjusted models for: BMI, alcohol consumption, educational level, leisure-time physical activity and smoking.

*Relevant confidence intervals.

Supplementary Table 4. Standardized unadjusted coefficient estimates from linear regression with $95 \%$ confidence intervals.

\begin{tabular}{|c|c|c|c|c|c|c|}
\hline & & HorvathAA & HannumAA & PhenoAgeAA & GrimAgeAA & DunedinPoAm \\
\hline & & Estimates (95\% CI) & Estimates (95\% CI) & Estimates (95\% CI) & Estimates (95\% CI) & Estimates (95\% CI) \\
\hline \multirow{3}{*}{ Job Status } & permanent & Ref. & Ref. & Ref. & Ref. & Ref. \\
\hline & temporary & $\begin{array}{c}-0.319 \\
(-0.63,-0.008)^{*}\end{array}$ & $\begin{array}{c}-0.275 \\
(-0.586,0.036)\end{array}$ & $\begin{array}{c}0.027 \\
(-0.284,0.339)\end{array}$ & $\begin{array}{c}0.149 \\
(-0.162,0.459)\end{array}$ & $\begin{array}{c}0.202 \\
(-0.109,0.513)\end{array}$ \\
\hline & unemployed & $\begin{array}{c}0.053 \\
(-0.29,0.395)\end{array}$ & $\begin{array}{c}0.035 \\
(-0.308,0.378)\end{array}$ & $\begin{array}{c}0.186 \\
(-0.157,0.529)\end{array}$ & $0.427(0.085,0.768)^{*}$ & $\begin{array}{c}0.27 \\
(-0.072,0.613)\end{array}$ \\
\hline \multirow[b]{2}{*}{ Employer } & private employer & Ref. & Ref. & Ref. & Ref. & Ref. \\
\hline & state/municipality & $\begin{array}{c}-0.085 \\
(-0.253,0.083)\end{array}$ & $\begin{array}{c}-0.085 \\
(-0.253,0.083)\end{array}$ & $\begin{array}{c}0.039 \\
(-0.129,0.207)\end{array}$ & $\begin{array}{c}-0.299 \\
(-0.462,-0.135)\end{array}$ & $\begin{array}{c}-0.079 \\
(-0.245,0.086)\end{array}$ \\
\hline \multirow{2}{*}{$\begin{array}{l}\text { Occupational } \\
\text { group }\end{array}$} & Blue collars & Ref. & Ref. & Ref. & Ref. & Ref. \\
\hline & White collars & $\begin{array}{c}0.034 \\
(-0.137,0.205)\end{array}$ & $\begin{array}{c}0.03 \\
(-0.142,0.201)\end{array}$ & $\begin{array}{c}0.001 \\
(-0.17,0.172)\end{array}$ & $\begin{array}{c}-0.355 \\
(-0.521,-0.188)^{*}\end{array}$ & $\begin{array}{c}-0.208 \\
(-0.374,-0.042)^{*}\end{array}$ \\
\hline Job control & & $\begin{array}{c}0.082 \\
(-0.027,0.191)\end{array}$ & $\begin{array}{c}0.066 \\
(-0.043,0.176)\end{array}$ & $\begin{array}{c}-0.047 \\
(-0.156,0.062)\end{array}$ & $\begin{array}{c}-0.055 \\
(-0.163,0.052)\end{array}$ & $\begin{array}{c}-0.062 \\
(-0.171,0.046)\end{array}$ \\
\hline Job demand & & $\begin{array}{c}0.006 \\
(-0.119,0.13)\end{array}$ & $\begin{array}{c}0.016 \\
(-0.109,0.141)\end{array}$ & $\begin{array}{c}-0.064 \\
(-0.189,0.061)\end{array}$ & $\begin{array}{c}-0.087 \\
(-0.21,0.036)\end{array}$ & $\begin{array}{c}-0.066 \\
(-0.189,0.058)\end{array}$ \\
\hline $\begin{array}{l}\text { Job strain } \\
\text { Linear }\end{array}$ & & $\begin{array}{c}-0.122 \\
(-0.314,0.07)\end{array}$ & $\begin{array}{c}-0.09 \\
(-0.282,0.102)\end{array}$ & $\begin{array}{c}-0.02 \\
(-0.211,0.171)\end{array}$ & $\begin{array}{c}-0.037 \\
(-0.226,0.151)\end{array}$ & $\begin{array}{c}-0.006 \\
(-0.195,0.184)\end{array}$ \\
\hline \multirow{4}{*}{ Job strain } & Low strain & Ref. & Ref. & Ref. & Ref. & Ref. \\
\hline & active work & $\begin{array}{c}0.038 \\
(-0.191,0.267)\end{array}$ & $\begin{array}{c}0.057 \\
(-0.173,0.286)\end{array}$ & $-0.25(-0.477,-0.023) *$ & $\begin{array}{c}-0.084 \\
(-0.308,0.14)\end{array}$ & $\begin{array}{c}-0.116 \\
(-0.342,0.109)\end{array}$ \\
\hline & passive work & $\begin{array}{c}0.028 \\
(-0.221,0.277)\end{array}$ & $\begin{array}{c}0.046 \\
(-0.203,0.296)\end{array}$ & $\begin{array}{c}-0.143 \\
(-0.39,0.104)\end{array}$ & $\begin{array}{c}0.052 \\
(-0.192,0.295)\end{array}$ & $\begin{array}{c}0.054 \\
(-0.191,0.299)\end{array}$ \\
\hline & high strain & $\begin{array}{c}-0.089 \\
(-0.337,0.16)\end{array}$ & $\begin{array}{c}-0.075 \\
(-0.324,0.174)\end{array}$ & $-0.055(-0.301,0.192)$ & $\begin{array}{c}0.004 \\
(-0.24,0.248)\end{array}$ & $\begin{array}{c}0.071 \\
(-0.173,0.316)\end{array}$ \\
\hline $\begin{array}{l}\text { Job strain } \\
\text { quotient }\end{array}$ & & $\begin{array}{c}-0.234 \\
(-0.521,0.053)\end{array}$ & $\begin{array}{c}-0.186 \\
(-0.474,0.101)\end{array}$ & $\begin{array}{c}-0.048 \\
(-0.334,0.238)\end{array}$ & $\begin{array}{c}0.014 \\
(-0.267,0.296)\end{array}$ & $\begin{array}{c}0.011 \\
(-0.272,0.294)\end{array}$ \\
\hline \multirow{3}{*}{$\begin{array}{l}\text { Job strain } \\
\text { tertile }\end{array}$} & Low strain & Ref. & Ref. & Ref. & Ref. & Ref. \\
\hline & $\begin{array}{l}\text { Intermediate } \\
\text { strain }\end{array}$ & $\begin{array}{c}-0.12 \\
(-0.328,0.088)\end{array}$ & $\begin{array}{c}-0.079 \\
(-0.287,0.129)\end{array}$ & $\begin{array}{c}-0.214 \\
(-0.42,-0.007)^{*}\end{array}$ & $\begin{array}{c}0.01 \\
(-0.194,0.214)\end{array}$ & $-0.002(-0.207,0.203)$ \\
\hline & high strain & $\begin{array}{c}-0.11 \\
(-0.318,0.097)\end{array}$ & $\begin{array}{c}-0.085 \\
(-0.292,0.123)\end{array}$ & $\begin{array}{c}-0.04 \\
(-0.246,0.166)\end{array}$ & $\begin{array}{c}-0.108 \\
(-0.311,0.095)\end{array}$ & $\begin{array}{c}-0.009 \\
(-0.214,0.196)\end{array}$ \\
\hline Effort & & $\begin{array}{c}-0.103 \\
(-0.227,0.021)\end{array}$ & $\begin{array}{c}-0.104 \\
(-0.228,0.02)\end{array}$ & $\begin{array}{c}-0.051 \\
(-0.176,0.074)\end{array}$ & $\begin{array}{c}0.186 \\
(0.063,0.308)^{*}\end{array}$ & $\begin{array}{c}0.136 \\
(0.012,0.26)^{*}\end{array}$ \\
\hline Reward & & 0.022 & 0.059 & 0.049 & 0.08 & $0.03(-0.122,0.183)$ \\
\hline
\end{tabular}




\begin{tabular}{|c|c|c|c|c|c|c|}
\hline & & $(-0.132,0.176)$ & $(-0.095,0.214)$ & $(-0.105,0.204)$ & $(-0.071,0.232)$ & \\
\hline $\begin{array}{l}\text { Effort-Reward } \\
\text { Imbalance }\end{array}$ & & $\begin{array}{c}-0.131 \\
(-0.341,0.079)\end{array}$ & $\begin{array}{c}-0.151 \\
(-0.361,0.059)\end{array}$ & $\begin{array}{c}-0.082 \\
(-0.294,0.129)\end{array}$ & $\begin{array}{c}0.195 \\
(-0.012,0.401)\end{array}$ & $\begin{array}{c}0.159 \\
(-0.049,0.367)\end{array}$ \\
\hline $\begin{array}{l}\text { Overcommitm } \\
\text { ent }\end{array}$ & & $\begin{array}{c}0.043 \\
(-0.088,0.173)\end{array}$ & $\begin{array}{c}0.034 \\
(-0.097,0.165)\end{array}$ & $\begin{array}{c}0.027 \\
(-0.104,0.158)\end{array}$ & $\begin{array}{c}0.036 \\
(-0.094,0.166)\end{array}$ & $\begin{array}{c}0 \\
(-0.132,0.131)\end{array}$ \\
\hline \multirow{2}{*}{ Work history } & $\begin{array}{l}\text { At least temporary } \\
\text { unemployed }\end{array}$ & Ref. & Ref. & Ref. & Ref. & Ref. \\
\hline & $\begin{array}{l}\text { Continuously } \\
\text { Employed }\end{array}$ & $\begin{array}{c}0.059 \\
(-0.102,0.22)\end{array}$ & $\begin{array}{c}0.08 \\
(-0.081,0.241)\end{array}$ & $\begin{array}{c}-0.023 \\
(-0.184,0.138)\end{array}$ & $\begin{array}{c}-0.163 \\
(-0.324,-0.002)^{*}\end{array}$ & $\begin{array}{c}-0.141 \\
(-0.302,0.02)\end{array}$ \\
\hline $\begin{array}{l}\text { Occupational } \\
\text { Physical } \\
\text { Activity }\end{array}$ & Low Intensity & Ref. & Ref. & Ref. & Ref. & Ref. \\
\hline \multirow{2}{*}{ strenuousness } & $\begin{array}{l}\text { Intermediate } \\
\text { Intensity }\end{array}$ & $\begin{array}{c}-0.07 \\
(-0.325,0.185)\end{array}$ & $\begin{array}{c}-0.05 \\
(-0.305,0.206)\end{array}$ & $0.093(-0.164,0.35)$ & $0.335(0.084,0.587)^{*}$ & $\begin{array}{c}0.183 \\
(-0.072,0.439)\end{array}$ \\
\hline & High Intensity & $\begin{array}{c}0.016 \\
(-0.235,0.268)\end{array}$ & $\begin{array}{c}0.053 \\
(-0.199,0.305)\end{array}$ & $0.157(-0.097,0.41)$ & $\begin{array}{c}0.166 \\
(-0.082,0.415)\end{array}$ & $\begin{array}{c}-0.048 \\
(-0.3,0.204)\end{array}$ \\
\hline \multirow{3}{*}{$\begin{array}{l}\text { Working hours } \\
\text { per week }\end{array}$} & less than 31 hours & Ref. & Ref. & Ref. & Ref. & Ref. \\
\hline & $31-40$ hours & $\begin{array}{c}0.311 \\
(-0.045,0.667)\end{array}$ & $\begin{array}{c}0.321 \\
(-0.036,0.677)\end{array}$ & $\begin{array}{c}-0.108 \\
(-0.469,0.253)\end{array}$ & $\begin{array}{c}0.011 \\
(-0.345,0.366)\end{array}$ & $\begin{array}{c}-0.022 \\
(-0.382,0.337)\end{array}$ \\
\hline & $\begin{array}{l}\text { more than } 40 \\
\text { hours }\end{array}$ & $\begin{array}{c}0.513 \\
(0.129,0.898)^{*}\end{array}$ & $0.524(0.139,0.909)^{*}$ & $\begin{array}{c}0.018 \\
(-0.372,0.407)\end{array}$ & $\begin{array}{c}0.14 \\
(-0.243,0.524)\end{array}$ & $\begin{array}{c}0.011 \\
(-0.376,0.399)\end{array}$ \\
\hline \multirow[b]{2}{*}{ Working shift } & Day job & Ref. & Ref. & Ref. & Ref. & Ref. \\
\hline & Evening/shift & $\begin{array}{c}0.113 \\
(-0.095,0.322)\end{array}$ & $\begin{array}{c}0.131 \\
(-0.079,0.341)\end{array}$ & $\begin{array}{c}0.122 \\
(-0.089,0.333)\end{array}$ & $\begin{array}{c}0.18 \\
(-0.028,0.387)\end{array}$ & $\begin{array}{c}0.217 \\
(0.008,0.426)^{*}\end{array}$ \\
\hline Work attitude & & $\begin{array}{c}-0.001 \\
(-0.024,0.022)\end{array}$ & $\begin{array}{c}-0.003 \\
(-0.026,0.02)\end{array}$ & $\begin{array}{c}-0.001 \\
(-0.024,0.022)\end{array}$ & $\begin{array}{c}-0.01 \\
(-0.033,0.013)\end{array}$ & $\begin{array}{c}-0.013 \\
(-0.036,0.009)\end{array}$ \\
\hline $\begin{array}{l}\text { Work } \\
\text { engagement }\end{array}$ & & $\begin{array}{c}0.001 \\
(-0.007,0.009)\end{array}$ & $\begin{array}{c}0.001 \\
(-0.007,0.009)\end{array}$ & $\begin{array}{c}0.002 \\
(-0.006,0.01)\end{array}$ & $\begin{array}{c}-0.012 \\
(-0.02,-0.004)^{*}\end{array}$ & $\begin{array}{c}-0.009 \\
(-0.017,-0.001)^{*}\end{array}$ \\
\hline \multirow[b]{2}{*}{ Job security } & No & Ref. & Ref. & Ref. & Ref. & Ref. \\
\hline & Yes & $0.254(0.022,0.485)^{*}$ & $\begin{array}{c}0.26 \\
(0.028,0.492)^{*} \\
\end{array}$ & $\begin{array}{c}0.182 \\
(-0.052,0.416) \\
\end{array}$ & $\begin{array}{c}-0.027 \\
(-0.258,0.204) \\
\end{array}$ & $\begin{array}{c}-0.072 \\
(-0.305,0.16) \\
\end{array}$ \\
\hline
\end{tabular}

* Relevant confidence intervals.

Supplementary Table 5. Standardized adjusted linear regression coefficient estimates with $95 \%$ confidence interval for the epigenetic age and pace of aging.

\begin{tabular}{|c|c|c|c|c|c|c|}
\hline & & $\begin{array}{c}\text { HorvathAA } \\
\text { Estimates } \\
(95 \% \text { CI }) \\
\end{array}$ & $\begin{array}{c}\text { HannumAA } \\
\text { Estimates } \\
(95 \% \mathrm{CI}) \\
\end{array}$ & $\begin{array}{c}\text { PhenoAgeAA } \\
\text { Estimates } \\
(95 \% \text { CI }) \\
\end{array}$ & $\begin{array}{c}\text { GrimAgeAA } \\
\text { Estimates }(95 \% \\
\text { CI) }\end{array}$ & $\begin{array}{c}\text { DunedinPoAm } \\
\text { Estimates } \\
(95 \% \mathrm{CI}) \\
\end{array}$ \\
\hline \multirow{3}{*}{ Job Status } & permanent & Ref. & Ref. & Ref. & Ref. & Ref. \\
\hline & temporary & $\begin{array}{c}-1.127 \\
(-2.422,0.168)\end{array}$ & $\begin{array}{c}-0.694 \\
(-1.661,0.272)\end{array}$ & $\begin{array}{c}-0.505 \\
(-2.017,1.008)\end{array}$ & $\begin{array}{c}0.631 \\
(-0.341,1.602)\end{array}$ & $\begin{array}{c}0.005 \\
(-0.013,0.023)\end{array}$ \\
\hline & unemployed & $\begin{array}{c}0.063 \\
(-1.325,1.451)\end{array}$ & $\begin{array}{c}-0.006 \\
(-1.042,1.03)\end{array}$ & $\begin{array}{c}0.817 \\
(-0.804,2.438)\end{array}$ & $\begin{array}{c}0.602 \\
(-0.439,1.644)\end{array}$ & $\begin{array}{c}0.004 \\
(-0.015,0.023)\end{array}$ \\
\hline \multirow[b]{2}{*}{ Employer } & private employer & Ref. & Ref. & Ref. & Ref. & Ref. \\
\hline & state/municipality & $\begin{array}{c}0.563 \\
(-0.42,1.546)\end{array}$ & $\begin{array}{c}0.297 \\
(-0.441,1.034)\end{array}$ & $\begin{array}{c}0.415 \\
(-0.736,1.567)\end{array}$ & $\begin{array}{c}0.25 \\
(-0.454,0.953)\end{array}$ & $\begin{array}{c}0.003 \\
(-0.01,0.017)\end{array}$ \\
\hline \multirow[b]{2}{*}{ Occupational group } & Blue collars & Ref. & Ref. & Ref. & Ref. & Ref. \\
\hline & White collars & $\begin{array}{c}-0.509 \\
(-1.292,0.274)\end{array}$ & $\begin{array}{c}-0.318 \\
(-0.905,0.268)\end{array}$ & $\begin{array}{c}-0.257 \\
(-1.166,0.653)\end{array}$ & $\begin{array}{c}0.683 \\
(0.102,1.264)^{*}\end{array}$ & $\begin{array}{c}0.002 \\
(-0.008,0.013)\end{array}$ \\
\hline Job control & & $\begin{array}{c}0.317 \\
(-0.149,0.782)\end{array}$ & $\begin{array}{c}0.169 \\
(-0.179,0.517)\end{array}$ & $\begin{array}{c}-0.186 \\
(-0.73,0.359)\end{array}$ & $\begin{array}{c}-0.154 \\
(-0.508,0.199)\end{array}$ & $\begin{array}{c}-0.001 \\
(-0.007,0.006)\end{array}$ \\
\hline Job demand & & $\begin{array}{c}0.086 \\
(-0.446,0.618)\end{array}$ & $\begin{array}{c}0.118 \\
(-0.279,0.514)\end{array}$ & $\begin{array}{c}-0.483 \\
(-1.103,0.137)\end{array}$ & $\begin{array}{c}-0.018 \\
(-0.42,0.384)\end{array}$ & $\begin{array}{c}-0.004(- \\
0.012,0.003)\end{array}$ \\
\hline Job strain Linear & & $\begin{array}{c}-0.41 \\
(-1.234,0.415)\end{array}$ & $\begin{array}{c}-0.154 \\
(-0.769,0.462)\end{array}$ & $\begin{array}{c}-0.354 \\
(-1.314,0.605)\end{array}$ & $\begin{array}{c}0.157 \\
(-0.465,0.779)\end{array}$ & $\begin{array}{c}-0.005 \\
(-0.017,0.006)\end{array}$ \\
\hline Job strain & Low strain & Ref. & Ref. & Ref. & Ref. & Ref. \\
\hline
\end{tabular}




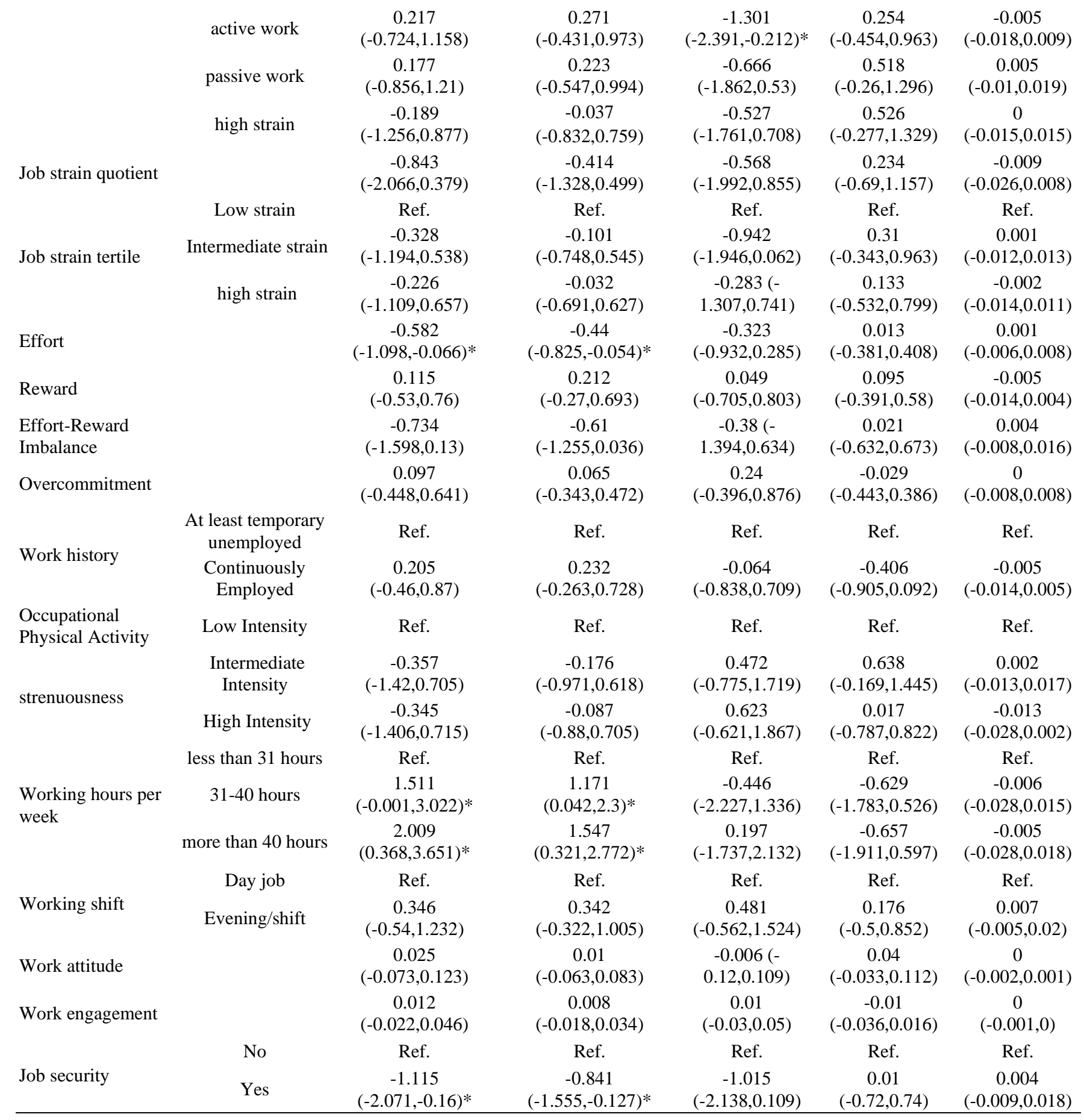

Fully adjusted models for: BMI, alcohol consumption, educational level, leisure-time physical activity and smoking. * Relevant confidence intervals. 
Supplementary Table 6 . Women adjusted linear regression coefficient estimates with $95 \%$ confidence interval for the epigenetic age and pace of aging.

\begin{tabular}{|c|c|c|c|c|c|c|}
\hline & & HorvathAA & HannumAA & PhenoAgeAA & GrimAgeAA & DunedinPoAm \\
\hline & & $\begin{array}{c}\text { Estimates } \\
(95 \% \mathrm{CI}) \\
\end{array}$ & $\begin{array}{c}\text { Estimates } \\
(95 \% \mathrm{CI})\end{array}$ & $\begin{array}{c}\text { Estimates } \\
(95 \% \text { CI }) \\
\end{array}$ & $\begin{array}{c}\text { Estimates } \\
(95 \% \text { CI }) \\
\end{array}$ & $\begin{array}{l}\text { Estimates } \\
(95 \% \mathrm{CI}) \\
\end{array}$ \\
\hline \multirow{3}{*}{ Job Status } & permanent & Ref. & Ref. & Ref. & Ref. & Ref. \\
\hline & temporary & $\begin{array}{c}-1.484 \\
(-2.922,-0.047) *\end{array}$ & $\begin{array}{c}-0.998 \\
(-2.079,0.082)\end{array}$ & $\begin{array}{c}-0.889 \\
(-2.592,0.813)\end{array}$ & $\begin{array}{c}0.762 \\
(-0.298,1.822)\end{array}$ & $\begin{array}{c}0.002 \\
(-0.018,0.023)\end{array}$ \\
\hline & unemployed & $\begin{array}{c}0.012 \\
(-2.01,2.034)\end{array}$ & $\begin{array}{c}-0.128 \\
(-1.648,1.392)\end{array}$ & $\begin{array}{c}1.125 \\
(-1.27,3.52)\end{array}$ & $\begin{array}{c}1.463 \\
(-0.028,2.955)\end{array}$ & $\begin{array}{c}0.009 \\
(-0.019,0.038)\end{array}$ \\
\hline & private employer & Ref. & Ref. & Ref. & Ref. & Ref. \\
\hline Employer & state/municipality & $\begin{array}{c}0.563 \\
(-0.42,1.546)\end{array}$ & $\begin{array}{c}0.297 \\
(-0.441,1.034)\end{array}$ & $\begin{array}{c}0.415 \\
(-0.736,1.567)\end{array}$ & $\begin{array}{c}0.25 \\
(-0.454,0.953)\end{array}$ & $\begin{array}{c}0.003 \\
(-0.01,0.017)\end{array}$ \\
\hline \multirow[b]{2}{*}{ Occupational group } & Blue collars & Ref. & Ref. & Ref. & Ref. & Ref. \\
\hline & White collars & $\begin{array}{c}0.557 \\
(-0.482,1.596)\end{array}$ & $\begin{array}{c}0.447 \\
(-0.332,1.225)\end{array}$ & $\begin{array}{c}0.577 \\
(-0.622,1.776)\end{array}$ & $\begin{array}{c}-0.306 \\
(-1.063,0.451)\end{array}$ & $\begin{array}{c}0.007 \\
(-0.007,0.022)\end{array}$ \\
\hline Job control & & $\begin{array}{c}0.413 \\
(-0.219,1.045)\end{array}$ & $\begin{array}{c}0.297 \\
(-0.177,0.77)\end{array}$ & $\begin{array}{c}-0.079 \\
(-0.818,0.659)\end{array}$ & $\begin{array}{c}-0.285 \\
(-0.749,0.178)\end{array}$ & $\begin{array}{c}0.005 \\
(-0.004,0.014)\end{array}$ \\
\hline Job demand & & $\begin{array}{c}0.203 \\
(-0.549,0.954)\end{array}$ & $\begin{array}{c}0.262 \\
(-0.299,0.824)\end{array}$ & $\begin{array}{c}-0.377 \\
(-1.251,0.498)\end{array}$ & $\begin{array}{c}0.271 \\
(-0.279,0.82)\end{array}$ & $\begin{array}{c}0.002 \\
(-0.008,0.013)\end{array}$ \\
\hline Job strain Linear & & $\begin{array}{c}-0.398 \\
(-1.485,0.689)\end{array}$ & $\begin{array}{c}-0.185(- \\
0.999,0.629)\end{array}$ & $\begin{array}{c}-0.435 \\
(-1.694,0.824)\end{array}$ & $\begin{array}{c}0.603 \\
(-0.184,1.389)\end{array}$ & $\begin{array}{c}-0.006 \\
(-0.022,0.009)\end{array}$ \\
\hline \multirow{4}{*}{ Job strain } & Low strain & Ref. & Ref. & Ref. & Ref. & Ref. \\
\hline & active work & $\begin{array}{c}0.411 \\
(-0.964,1.786)\end{array}$ & $\begin{array}{c}0.393 \\
(-0.634,1.421)\end{array}$ & $\begin{array}{c}-1.414 \\
(-3.006,0.179)\end{array}$ & $\begin{array}{c}0.501 \\
(-0.499,1.5)\end{array}$ & $\begin{array}{c}0.004 \\
(-0.015,0.023)\end{array}$ \\
\hline & passive work & $\begin{array}{c}0.38 \\
(-1.156,1.917)\end{array}$ & $\begin{array}{c}0.298 \\
(-0.85,1.446)\end{array}$ & $\begin{array}{c}-0.915 \\
(-2.694,0.864)\end{array}$ & $\begin{array}{c}0.316 \\
(-0.801,1.433)\end{array}$ & $\begin{array}{c}-0.003 \\
(-0.025,0.019)\end{array}$ \\
\hline & high strain & $\begin{array}{c}-0.611 \\
(-2.006,0.784)\end{array}$ & $\begin{array}{c}-0.502 \\
(-1.544,0.54)\end{array}$ & $\begin{array}{c}-1.188 \\
(-2.803,0.427)\end{array}$ & $\begin{array}{c}0.754 \\
(-0.26,1.768)\end{array}$ & $\begin{array}{c}-0.003 \\
(-0.022,0.017)\end{array}$ \\
\hline Job strain quotient & & $\begin{array}{c}-1.009 \\
(-2.579,0.561)\end{array}$ & $\begin{array}{c}-0.525 \\
(-1.701,0.652)\end{array}$ & $\begin{array}{c}-0.727 \\
(-2.549,1.094)\end{array}$ & $\begin{array}{c}0.728 \\
(-0.412,1.867)\end{array}$ & $\begin{array}{c}-0.014 \\
(-0.036,0.008)\end{array}$ \\
\hline \multirow{3}{*}{ Job strain tertile } & Low strain & Ref. & Ref. & Ref. & Ref. & Ref. \\
\hline & Intermediate strain & $\begin{array}{c}0.055 \\
(-1.198,1.309)\end{array}$ & $\begin{array}{c}0.198 \\
(-0.74,1.136)\end{array}$ & $\begin{array}{c}-0.958 \\
(-2.407,0.491)\end{array}$ & $\begin{array}{c}0.216 \\
(-0.692,1.124)\end{array}$ & $\begin{array}{c}-0.009 \\
(-0.026,0.009)\end{array}$ \\
\hline & high strain & $\begin{array}{c}-0.21 \\
(-1.397,0.977)\end{array}$ & $\begin{array}{c}-0.148 \\
(-1.036,0.74)\end{array}$ & $\begin{array}{c}-0.567 \\
(-1.939,0.805)\end{array}$ & $\begin{array}{c}0.541 \\
(-0.319,1.401)\end{array}$ & $\begin{array}{c}-0.007 \\
(-0.023,0.01)\end{array}$ \\
\hline Effort & & $\begin{array}{c}-0.985 \\
(-1.67,-0.3) *\end{array}$ & $\begin{array}{c}-0.679 \\
(-1.193,-0.165) *\end{array}$ & $\begin{array}{c}-0.737 \\
(-1.547,0.072)\end{array}$ & $\begin{array}{c}-0.362 \\
(-0.874,0.149)\end{array}$ & $\begin{array}{c}-0.006 \\
(-0.016,0.004)\end{array}$ \\
\hline Reward & & $\begin{array}{c}-0.007 \\
(-0.881,0.866)\end{array}$ & $\begin{array}{c}0.06 \\
(-0.596,0.715)\end{array}$ & $\begin{array}{c}-0.223 \\
(-1.243,0.796)\end{array}$ & $\begin{array}{c}0.596 \\
(-0.03,1.223)\end{array}$ & $\begin{array}{c}-0.003 \\
(-0.015,0.01)\end{array}$ \\
\hline $\begin{array}{l}\text { Effort-Reward } \\
\text { Imbalance }\end{array}$ & & $\begin{array}{c}-1.292 \\
(-2.486,-0.099) *\end{array}$ & $\begin{array}{c}-0.915 \\
(-1.812,-0.019) *\end{array}$ & $\begin{array}{c}-0.669 \\
(-2.075,0.737)\end{array}$ & $\begin{array}{c}-0.769 \\
(-1.635,0.096)\end{array}$ & $\begin{array}{c}-0.007 \\
(-0.024,0.009)\end{array}$ \\
\hline Overcommitment & & $\begin{array}{c}-0.482 \\
(-1.189,0.224)\end{array}$ & $\begin{array}{c}-0.339 \\
(-0.868,0.191)\end{array}$ & $\begin{array}{c}-0.193 \\
(-1.019,0.632)\end{array}$ & $\begin{array}{c}-0.331 \\
(-0.853,0.192)\end{array}$ & $\begin{array}{c}-0.006 \\
(-0.016,0.005)\end{array}$ \\
\hline \multirow{2}{*}{ Work history } & $\begin{array}{l}\text { At least temporary } \\
\text { unemployed }\end{array}$ & Ref. & Ref. & Ref. & Ref. & Ref. \\
\hline & $\begin{array}{l}\text { Continuously } \\
\text { Employed }\end{array}$ & $\begin{array}{c}0.201 \\
(-0.685,1.087)\end{array}$ & $\begin{array}{c}0.38 \\
(-0.283,1.043)\end{array}$ & $\begin{array}{c}0.169 \\
(-0.87,1.208)\end{array}$ & $\begin{array}{c}-0.659(- \\
1.309,-0.009) *\end{array}$ & $\begin{array}{c}-0.004 \\
(-0.016,0.009)\end{array}$ \\
\hline \multirow{3}{*}{$\begin{array}{l}\text { Occupational } \\
\text { Physical Activity }\end{array}$} & Low Intensity & Ref. & Ref. & Ref. & Ref. & Ref. \\
\hline & $\begin{array}{l}\text { Intermediate } \\
\text { Intensity }\end{array}$ & $\begin{array}{c}-0.361 \\
(-1.82,1.098)\end{array}$ & $\begin{array}{c}-0.153 \\
(-1.243,0.937)\end{array}$ & $\begin{array}{c}0.481 \\
(-1.227,2.189)\end{array}$ & $\begin{array}{c}-0.12 \\
(-1.202,0.963)\end{array}$ & $\begin{array}{c}-0.006 \\
(-0.027,0.015)\end{array}$ \\
\hline & High Intensity & $\begin{array}{c}1.3 \\
(-0.253,2.853)\end{array}$ & $\begin{array}{c}1.248 \\
(0.088,2.408) *\end{array}$ & $\begin{array}{c}1.519 \\
(-0.299,3.337)\end{array}$ & $\begin{array}{c}0.127 \\
(-1.025,1.279)\end{array}$ & $\begin{array}{c}-0.01 \\
(-0.033,0.012)\end{array}$ \\
\hline
\end{tabular}




\begin{tabular}{lcccccc} 
& less than 31 hours & Ref. & Ref. & Ref. & Ref. & Ref. \\
Working hours per & & 1.509 & 1.345 & -0.558 & -0.681 & -0.013 \\
week & 31-40 hours & $(-0.245,3.262)$ & $(0.034,2.655) *$ & $(-2.613,1.497)$ & $(-1.984,0.623)$ & $(-0.038,0.011)$ \\
& & 2.483 & 2.075 & 1.17 & -0.393 & 0.003 \\
& more than 40 hours & $(0.421,4.546) *$ & $(0.534,3.616) *$ & $(-1.246,3.587)$ & $(-1.926,1.141)$ & $(-0.027,0.032)$ \\
Working shift & Day job & Ref. & Ref. & Ref. & Ref. & Ref. \\
& Evening/shift & 0.385 & 0.243 & 0.494 & -0.077 & -0.005 \\
Work attitude & & $(-0.819,1.588)$ & $(-0.662,1.148)$ & $(-0.92,1.909)$ & $(-0.972,0.817)$ & $(-0.022,0.012)$ \\
& & 0.045 & 0.033 & 0.076 & 0.002 & 0 \\
Work engagement & & $(-0.083,0.174)$ & $(-0.064,0.129)$ & $(-0.075,0.228)$ & $(-0.091,0.095)$ & $(-0.002,0.002)$ \\
& & 0.01 & 0.01 & 0.04 & -0.008 & 0 \\
Job security & \multirow{2}{*}{ No } & $(-0.037,0.056)$ & $(-0.025,0.044)$ & $(-0.015,0.094)$ & $(-0.043,0.027)$ & $(-0.001,0.001)$ \\
& Yes & Ref. & Ref. & Ref. & Ref. & Ref. \\
& & 1.06 & 0.617 & 0.535 & -0.668 & -0.012 \\
\hline
\end{tabular}

Fully adjusted models for: BMI, alcohol consumption, educational level, leisure-time physical activity and smoking.

*Relevant confidence intervals.

Supplementary Table 7. Men adjusted linear regression coefficient estimates with $95 \%$ confidence interval for the epigenetic age and pace of aging.

\begin{tabular}{|c|c|c|c|c|c|c|}
\hline & & HorvathAA & HannumAA & PhenoAgeAA & GrimAgeAA & DunedinPoAm \\
\hline & & $\begin{array}{c}\text { Estimates }(95 \% \\
\text { CI) }\end{array}$ & $\begin{array}{c}\text { Estimates } \\
(95 \% \mathrm{CI}) \\
\end{array}$ & $\begin{array}{c}\text { Estimates } \\
(95 \% \text { CI }) \\
\end{array}$ & $\begin{array}{c}\text { Estimates } \\
(95 \% \mathrm{CI}) \\
\end{array}$ & $\begin{array}{l}\text { Estimates } \\
(95 \% \mathrm{CI})\end{array}$ \\
\hline \multirow{3}{*}{ Job Status } & permanent & Ref. & Ref. & Ref. & Ref. & Ref. \\
\hline & temporary & $\begin{array}{c}0.119 \\
(-2.855,3.093)\end{array}$ & $\begin{array}{c}0.354 \\
(-1.849,2.558)\end{array}$ & $\begin{array}{c}0.786 \\
(-2.598,4.169)\end{array}$ & $\begin{array}{c}0.031 \\
(-2.222,2.285)\end{array}$ & $\begin{array}{c}0.019 \\
(-0.022,0.059)\end{array}$ \\
\hline & unemployed & $\begin{array}{c}-0.225 \\
(-2.213,1.763)\end{array}$ & $\begin{array}{c}-0.11 \\
(-1.584,1.363)\end{array}$ & $\begin{array}{c}0.276 \\
(-1.986,2.538)\end{array}$ & $\begin{array}{c}-0.264 \\
(-1.771,1.243)\end{array}$ & $\begin{array}{c}-0.003 \\
(-0.03,0.024)\end{array}$ \\
\hline \multirow[b]{2}{*}{ Employer } & private employer & Ref. & Ref. & Ref. & Ref. & Ref. \\
\hline & state/municipality & $\begin{array}{c}-0.581 \\
(-1.878,0.716)\end{array}$ & $\begin{array}{c}-0.246 \\
(-1.217,0.724)\end{array}$ & $\begin{array}{c}-0.232 \\
(-1.732,1.269)\end{array}$ & $\begin{array}{c}-0.451 \\
(-1.43,0.528)\end{array}$ & $\begin{array}{c}-0.005 \\
(-0.023,0.013)\end{array}$ \\
\hline \multirow[b]{2}{*}{ Occupational group } & Blue collars & Ref. & Ref. & Ref. & Ref. & Ref. \\
\hline & White collars & $\begin{array}{c}0.433 \\
(-0.784,1.65)\end{array}$ & $\begin{array}{c}0.118 \\
(-0.794,1.03)\end{array}$ & $\begin{array}{c}-0.283 \\
(-1.705,1.139)\end{array}$ & $\begin{array}{c}-1.245 \\
(-2.164,-0.325) *\end{array}$ & $\begin{array}{c}-0.015 \\
(-0.032,0.001)\end{array}$ \\
\hline Job control & & $\begin{array}{c}0.175 \\
(-0.535,0.885)\end{array}$ & $\begin{array}{c}0.001 \\
(-0.529,0.531)\end{array}$ & $\begin{array}{c}-0.316 \\
(-1.14,0.508)\end{array}$ & $\begin{array}{c}-0.029 \\
(-0.586,0.527)\end{array}$ & $\begin{array}{c}-0.007 \\
(-0.017,0.003)\end{array}$ \\
\hline Job demand & & $\begin{array}{c}-0.149 \\
(-0.932,0.633)\end{array}$ & $\begin{array}{c}-0.106 \\
(-0.69,0.478)\end{array}$ & $\begin{array}{c}-0.716 \\
(-1.619,0.187)\end{array}$ & $\begin{array}{c}-0.347 \\
(-0.957,0.264)\end{array}$ & $\begin{array}{c}-0.012 \\
(-0.023,-0.001) *\end{array}$ \\
\hline Job strain Linear & & $\begin{array}{c}-0.511 \\
(-1.815,0.794)\end{array}$ & $\begin{array}{c}-0.168 \\
(-1.142,0.807)\end{array}$ & $\begin{array}{c}-0.335 \\
(-1.845,1.175)\end{array}$ & $\begin{array}{c}-0.447 \\
(-1.468,0.574)\end{array}$ & $\begin{array}{c}-0.006 \\
(-0.025,0.012)\end{array}$ \\
\hline \multirow{3}{*}{ Job strain } & $\begin{array}{l}\text { Low strain } \\
\text { active work }\end{array}$ & $\begin{array}{c}\text { Ref. } \\
-0.211 \\
(-1.546,1.125)\end{array}$ & $\begin{array}{c}\text { Ref. } \\
-0.035 \\
(-1.028,0.958)\end{array}$ & $\begin{array}{c}\text { Ref. } \\
-1.458 \\
(-2.993,0.078)\end{array}$ & $\begin{array}{c}\text { Ref. } \\
-0.233 \\
(-1.276,0.811)\end{array}$ & $\begin{array}{c}\text { Ref. } \\
-0.016 \\
(-0.035,0.002)\end{array}$ \\
\hline & passive work & $\begin{array}{c}-0.095 \\
(-1.526,1.336)\end{array}$ & $\begin{array}{c}0.102 \\
(-0.962,1.167)\end{array}$ & $\begin{array}{c}-0.458 \\
(-2.103,1.188)\end{array}$ & $\begin{array}{c}0.625 \\
(-0.493,1.744)\end{array}$ & $\begin{array}{c}0.012 \\
(-0.008,0.032)\end{array}$ \\
\hline & high strain & $\begin{array}{c}0.965 \\
(-0.873,2.803)\end{array}$ & $\begin{array}{c}1.104 \\
(-0.263,2.47)\end{array}$ & $\begin{array}{c}0.212 \\
(-1.9,2.325)\end{array}$ & $\begin{array}{c}0.105 \\
(-1.331,1.541)\end{array}$ & $0.004(-0.021,0.03)$ \\
\hline \multirow[t]{2}{*}{ Job strain quotient } & & $\begin{array}{c}-0.749 \\
(-2.776,1.278)\end{array}$ & $\begin{array}{c}-0.365 \\
(-1.878,1.148)\end{array}$ & $\begin{array}{c}-0.585 \\
(-2.93,1.761)\end{array}$ & $\begin{array}{c}-0.454 \\
(-2.041,1.133)\end{array}$ & $\begin{array}{c}-0.005 \\
(-0.034,0.023)\end{array}$ \\
\hline & Low strain & Ref. & Ref. & Ref. & Ref. & Ref. \\
\hline \multirow[t]{2}{*}{ Job strain tertile } & Intermediate strain & $\begin{array}{c}-0.813 \\
(-2.053,0.427)\end{array}$ & $\begin{array}{c}-0.476 \\
(-1.401,0.448)\end{array}$ & $\begin{array}{c}-0.866 \\
(-2.3,0.569)\end{array}$ & $\begin{array}{c}0.367 \\
(-0.601,1.335)\end{array}$ & $\begin{array}{c}0.009 \\
(-0.008,0.027)\end{array}$ \\
\hline & high strain & $\begin{array}{c}-0.137 \\
(-1.517,1.243)\end{array}$ & $\begin{array}{c}0.25 \\
(-0.779,1.279)\end{array}$ & $\begin{array}{c}-0.011 \\
(-1.608,1.585)\end{array}$ & $\begin{array}{c}-0.586 \\
(-1.664,0.491)\end{array}$ & $\begin{array}{c}0 \\
(-0.02,0.02)\end{array}$ \\
\hline Effort & & $\begin{array}{c}-0.113 \\
(-0.916,0.689)\end{array}$ & $\begin{array}{c}-0.169 \\
(-0.768,0.43)\end{array}$ & $\begin{array}{c}0.253 \\
(-0.682,1.188)\end{array}$ & $\begin{array}{c}0.424 \\
(-0.203,1.05)\end{array}$ & $\begin{array}{c}0.011 \\
(-0.001,0.022)\end{array}$ \\
\hline
\end{tabular}


Reward

Effort-Reward

Imbalance

Overcommitment

Work history

Occupational

Physical Activity

week

Working shift

Work attitude

Work engagement

Job security

$\begin{array}{cc}0.389 & 0.462 \\ (-0.586,1.364) & (-0.264,1.187) \\ -0.283 & -0.377 \\ (-1.565,0.998) & (-1.331,0.578) \\ 0.85 & 0.575 \\ (-0.032,1.731) & (-0.086,1.237)\end{array}$

At least temporary unemployed Continuously Employed Low Intensity Intermediate Intensity

High Intensity

less than 31 hours

31-40 hours

more than 40 hours

Day job

Evening/shift

Yes

\section{Ref.}

0.258

$(-0.803,1.319)$

Ref.

$-0.258$

$(-1.859,1.343)$

$-1.775$

$(-3.283,-0.267)$ *

Ref.

1.854

$(-1.247,4.955)$

2.095

$(-1.089,5.278)$

Ref.

0.129

$(-1.211,1.468)$

$-0.014$

$(-0.172,0.144)$

0.012

$(-0.04,0.064)$

Ref.

1.293
$(-0.13,2.716)$
Ref.

0.08

$(-0.707,0.866)$

Ref.

$-0.132$

$(-1.33,1.066)$

$-1.22$

$(-2.348,-0.092) *$

Ref.

0.903

$(-1.416,3.223)$

1.072

$(-1.309,3.454)$

Ref.

0.339

$(-0.661,1.339)$

$-0.033$

$(-0.15,0.084)$

0.005

$(-0.034,0.043)$

Ref.

1.132 (0.072,2.191)
0.323
$(-0.805,1.451)$
0.016
$(-1.466,1.499)$
0.721
$(-0.306,1.749)$

Ref.

$-0.47$

$(-1.677,0.737)$

Ref.

0.764

$(-1.122,2.65)$

0.089

$(-1.688,1.865)$

Ref.

$-0.512$

$(-4.139,3.115)$

$-0.609$

$(-4.332,3.115)$

Ref.

0.229

$(-1.333,1.792)$

$-0.144$

$(-0.323,0.034)$

$-0.021$

$(-0.081,0.04)$

Ref.

1.407 $(-0.253,3.067)$
$-0.488$

$(-1.256,0.28)$

0.765

$(-0.242,1.771)$

0.3

$(-0.394,0.994)$

Ref.

$-0.005$

$(-0.81,0.799)$

Ref.

1.651

$(0.4,2.901) *$

0.378

$(-0.8,1.556)$

Ref.

$-0.497$

$(-2.931,1.938)$

$-0.884$

$(-3.383,1.616)$

Ref.

0.446

$(-0.598,1.491)$

0.073

$(-0.046,0.192)$

$-0.015$

$(-0.056,0.025)$

Ref.

0.69 $(-0.429,1.809)$
$-0.007$

$(-0.021,0.007)$

0.018

$(-0.001,0.036)$

0.008

$(-0.005,0.02)$

Ref.

$-0.006$

$(-0.02,0.009)$

Ref.

$0.013(-0.01,0.036)$

$-0.012$

$(-0.034,0.009)$

Ref.

0.015

$(-0.029,0.058)$

0.005

$(-0.04,0.05)$

Ref.

0.021

$(0.002,0.039) *$

$-0.001$

$(-0.003,0.001)$

$-0.001$

$(-0.001,0)$

Ref.

0.005 $(-0.015,0.026)$

Fully adjusted models for: BMI, alcohol consumption, educational level, leisure-time physical activity and smoking.

* Relevant confidence intervals. 